\title{
RESEARCH
}

\section{FOXL2 antagonises the male developmental pathway in embryonic chicken gonads}

\author{
Andrew T Major ${ }^{1 *}$, Katie L Ayers" , Justin Chue², Kelly N Roeszler², and Craig A Smith¹ \\ 1Department of Anatomy and Developmental Biology, Monash Biomedicine Discovery Institute, Monash University, Clayton, Victoria, Australia \\ 2Murdoch Childrens Research Institute, Royal Children's Hospital and University of Melbourne Departments of Paediatrics, Royal Children's Hospital, \\ Parkville, Victoria, Australia
}

Correspondence should be addressed to C A Smith: craig.smith@monash.edu

*(A Major and K Ayers contributed equally to this work)

\begin{abstract}
FOXL2 is a conserved transcription factor with a central role in ovarian development and function. Studies in humans and mice indicate that the main role of FOXL2 is in the postnatal ovary, namely folliculogenesis. To shed light on the function and evolution of FOXL2 in the female gonad, we examined its role in embryonic avian gonads, using in ovo overexpression and knockdown. FOXL2 MRNA and protein are expressed female specifically in the embryonic chicken gonad, just prior to the onset of sexual differentiation. FOXL2 is expressed in the medullary cord cells, in the same cell type as aromatase (CYP19A1). In addition, later in development, expression also becomes localised in a subset of cortical cells, distinct from those expressing oestrogen receptor alpha. Misexpression of FOXL2 in the male chicken embryonic gonad suppresses the testis developmental pathway, abolishing local expression of the male pathway genes SOX9, DMRT1 and AMH and repressing Sertoli cell development. Conversely, knockdown of FOXL2 expression allows ectopic activation of SOX9 in female gonads. However, misexpression of FOXL2 alone was insufficient to activate aromatase expression in male gonads, while FOXL2 knockdown did not affect aromatase expression in females. These results indicate that FOXL2 plays an important role in embryonic differentiation of the avian ovary via antagonism of SOX9, but may be dispensable for aromatase activation at embryonic stages. The data suggest that FOXL2 has different roles in different species, more central for embryonic ovarian differentiation in egg-laying vertebrates.
\end{abstract}

Key Words:
- FOXL2
- embryonic gonad
- chicken
- sex determination
- sexual differentiation
- ovary
- testis

\section{Introduction}

The forkhead box (FOX) family of transcription factors are conserved developmental regulators, playing diverse roles in cell differentiation, apoptosis and tumorigenesis (Brunet et al. 1999, Schmidt et al. 2002, Stahl et al. 2002, Lehmann et al. 2003, Krupczak-Hollis et al. 2004, Senokuchi et al. 2008, Ahn et al. 2015, Eelen et al. 2016, Deng et al. 2017). FOX proteins share a conserved 110 amino acid DNAbinding domain, the forkhead box, a so-called 'winged helix' (a helix-turn-helix core, flanked by two loops, or 'wings') (Clark et al. 1993, Katoh \& Katoh 2004). Fox proteins diverge in sequence outside the forkhead domain. They typically act as transcriptional activators, but can also act as repressors, and they often act in partnerships with co-factors (Uhlenhaut \& Treier 2006, Rosario et al. 2012). There are currently 19 recognised FOX subfamilies, designated A to S. One FOX gene, FOXL2, plays a central 
role in female reproductive function in vertebrates (Baron et al. 2005, Bertho et al. 2016). Its expression in mammals is restricted to the ovary, eyelids and pituitary gland. In the pituitary, FOXL2 is required for transcription of folliclestimulating hormone (FSH) (Ellsworth et al. 2006, Corpuz et al. 2010, Tran et al. 2013). FOXL2 also plays a key role in the ovary, where it is expressed in follicular (granulosa) cells (Cocquet et al. 2002, Uhlenhaut \& Treier 2006, Auguste et al. 2011). In the mouse, Foxl2 is required for postnatal granulosa cell development and maintenance. Although Foxl2 is expressed during embryonic stages, homozygous null mutant mice exhibit ovarian failure that only becomes apparent postnatally. Foxl2 $2^{-/-}$mice have impaired follicle formation characterised by granulosa cell dysfunction, extensive follicular atresia and sterility (Schmidt et al. 2004, Uda et al. 2004). The testis marker Sox9 also becomes expressed in Foxl2-/- gonads postnatally (Ottolenghi et al. 2005). However, loss of function can cause masculinisation during embryonic stages when the feminising genes, Wnt4 or R-Spo1, are also deleted (Ottolenghi et al. 2007, Auguste et al. 2011). In such compound mutants, Sertoli cells develop and testis markers such as Sox9 and Dmrt1 are expressed. Ectopic expression of Foxl2 in foetal mouse testes can cause partial sex reversal (at E14.5 and postnatally) (Nicol et al. 2018). Taken together the data indicate that Foxl2 does not play a central functional role in sexual differentiation of the gonads in mouse, but is more important in maintaining granulosa cell identity postnatally.

In mouse, Foxl2 is thought to be required to maintain the ovarian phenotype throughout life by actively repressing the male (testis) pathway, probably in conjunction with oestrogen (Ottolenghi et al. 2005, Garcia-Ortiz et al. 2009). Conditional loss of Foxl2 in adult mice can lead to 'trans-differentiation' of the gonad from ovary to testis, with granulosa cells losing females markers and expressing Sertoli cell markers, such as Sox9. Under these conditions, Foxl2 can act together with oestrogen receptor alpha to negatively regulate Sox9 (Uhlenhaut et al. 2009). In humans, heterozygous mutations in FOXL2 cause blepharophimosis/ptosis/epicanthus inversus syndrome (BPES), which includes eyelid and mild craniofacial defects associated with frequent premature ovarian failure and infertility (Crisponi et al. 2001, De Baere et al. 2001, Castro \& Trujillo 2002). FOXL2 in humans is required for granulosa cell maintenance (Kim et al. 2011, Kuo et al. 2011). Furthermore, disruption of FOXL2 can result in ovarian tumours (Benayoun et al. 2010). One missense mutation in FOXL2 (C134W) underlies over $90 \%$ of ovarian adult-type granulosa cell tumours (Beysen et al. 2004, Shah et al. 2009). Hence, in both mouse and human, FOXL2 has a key role in ovarian maintenance after birth, but may not itself be required for embryonic ovarian differentiation. One of its key roles is the regulation of gonadal steroidogenesis (Baron et al. 2004, Pisarska et al. 2004, Pannetier et al. 2006, Uhlenhaut $\&$ Treier 2006).

The exact role of Foxl2 during ovarian development appears to differ among vertebrate species. As noted above, FOXL2 is required postnatally in mouse and human, that is, after embryonic differentiation of the ovary. In goats, the FOXL2 gene is located $300 \mathrm{~kb}$ downstream of a critical $11.7 \mathrm{~kb}$ genomic region that is deleted and causes $\mathrm{XX}$ sex reversal associated with the Polled (hornless) intersex phenotype (Pailhoux et al. 2001). FOXL2 is expressed in XX foetal goat gonads and targeted deletion of the gene using zinc-finger nucleases leads to female-to-male sex reversal (Pailhoux et al. 2002, Boulanger et al. 2014). Embryonic XX gonads develop as testes rather than ovaries. These observations identify FOXL2 as a key ovarydetermining gene in goats, in contrast to its postnatal role in mice and humans. Among fishes, the Foxl2 gene is also expressed in an ovarian-specific manner in tilapia and targeted deletion also causes female-to-male sex reversal (Li et al. 2013, Zhang et al. 2017).

In the mammalian ovary, one of the direct targets of FOXL2 is considered to be CYP19A1, which encodes the rate-limiting enzyme involved in oestrogen synthesis, Aromatase (Pannetier et al. 2006, Fleming et al. 2010). FOXL2 can bind and activate the CYP19A1 promoter in mammals and in a fish, the Nile Tilapia (Batista et al. 2007, Wang et al. 2007, Fleming et al. 2010, Rosario et al. 2012). The potential interaction between FOXL2 and aromatase is especially noteworthy among nonmammalian vertebrates, because oestrogen synthesis plays a decisive role in ovarian differentiation at embryonic stages (Vaillant et al. 2001, Ramsey \& Crews 2009, Barske \& Capel 2010, Guiguen et al. 2010, Lambeth et al. 2013, Zhang et al. 2017). In these vertebrates, Foxl2 has an early, conserved female-specific expression pattern in the embryonic gonads. This applies to all species that have been examined, from fishes to reptiles and birds (Cocquet et al. 2003, Loffler et al. 2003, Rhen et al. 2007, Bertho et al . 2016, Hirst et al. 2017, Zhang et al. 2017, Bertho et al. 2018). In the chicken embryo, FOXL2 is expressed in female but not male embryonic gonads (Loffler et al. 2003, Govoroun et al. 2004, Hudson et al. 2005). Expression data in birds and reptiles suggest that FOXL2 may activate CYP19A1 in the gonad, as it does in mammals, but this has not been demonstrated. Elucidating the exact role of FOXL2 in avian 
gonadal development would be particularly useful. Firstly, it would shed light on the evolution of FOXL2 function in the vertebrate ovary. Secondly, the global poultry industry currently seeks methods of manipulating sex ratios (all female chickens are required by the egg industry, and males are preferred by the meat industry). If FOXL2 plays a central role in chicken ovarian development, it could offer a potential target for genetic manipulation and modifying sexual development. However, functional data are currently lacking, partly due to the technical difficulty of manipulating gene expression in avian embryonic gonads, and also producing knockout birds.

The aim of this study was to define the role of FOXL2 in ovarian development in the avian model. We first characterised the expression profile of FOXL2 prior to, during and after gonadal differentiation in the chicken embryo and determined the phenotypic consequences of experimentally manipulating its expression. We show that FOXL2 protein is expressed female-specifically prior to and during gonadal sex differentiation in the embryonic chicken gonad. FOXL2 protein is co-expressed with aromatase enzyme, but not with the oestrogen receptor alpha. In addition, there is a unique cortical shift of FOXL2 expression that occurs after the onset of meiosis. We find that misexpression of FOXL2 in genetic males acts to suppress testis markers but is insufficient to induce aromatase expression. Conversely, downregulation of FOXL2 expression in the female resulted in the upregulation of the male marker, SOX9, but it did not repress aromatase expression. These findings indicate that FOXL2 has a dynamic role in embryonic ovarian development in the chicken and that one of its primary functions is the suppression of the male pathway. The data enhance our understanding of FOXL2 function in the vertebrate gonad, and may provide a basis for genetic modification of sex in poultry.

\section{Materials and methods}

\section{Eggs}

Fertile eggs of the chicken (Gallus gallus domesticus) were obtained from Research Poultry Farm (Victoria, Australia) or Australian SPF Services (Victoria, Australia) and incubated in a Multiquip E3 egg incubator (Bellsouth Pty. Ltd.) at $37.4^{\circ} \mathrm{C}, 70-80 \%$ humidity with $90^{\circ}$ rotations at fixed intervals. Tissue samples were collected from embryos from various time points and the stage of development was determined as described by Hamburger and Hamilton (Hamburger \& Hamilton 1992). All embryos were genetically sexed by PCR as described previously, using genomic DNA obtained from limb tissue (Clinton et al. 2001). Briefly, ZW females were identified by the presence of a female-specific (W-linked) XhoI repeat sequence in addition to a $18 \mathrm{~S}$ ribosomal gene internal control. $\mathrm{ZZ}$ males showed the $18 \mathrm{~S}$ band only. All work involving the use of chicken embryos was performed in accordance with institution animal ethics regulations, approved under Murdoch Children's Research AEC \# A731 and Monash University AEC \# 16743.

\section{RNA-seq}

Total RNA was extracted from sexed blastoderms and from embryonic chicken gonads at E4.0 (prior to gonadal sex differentiation) and at E6.5 (the onset of sexual differentiation). RNA-seq was then preformed and this dataset was been published previously (Ayers et al. 2013). FOXL2 mRNA levels were extracted from this data. The RNA-seq was conducted in duplicate. Each replicate was a pool of several samples and we used statistical analysis that allows for duplicates. Specifically, edgeR was used for statistical analysis of differential FOXL2 expression between the sexes. EdgeR uses a Generalised Linear Modeling (GLM) framework to model the gene counts as a negative binomial distribution. Variation estimates are stabilised by borrowing information between genes using an empirical Bayes approach and hypothesis tests are performed using a likelihood ratio test. This method takes into account both biological and technical sources of variation even for small numbers of replicates, as here. We had three degrees of freedom to estimate biological variability, as described previously (Ayers et al. 2013).

\section{Immunofluorescence}

To precisely define the onset of FOXL2 protein expression relative to that of aromatase, immunofluorescence was used. Whole urogenital systems (comprising embryonic gonads and mesonephric kidneys) were collected from chicken embryos at E5.0 (HH stage 26-27), E5.5 (HH stage 28), E6.0 (HH stage 29), E7.0 (HH stage 31), E8.5 (HH stage 35), E10.5 (HH stage 36-37) and E14.5 (HH stage 40-41) for immunostaining analysis. Tissues were fixed in $4 \%$ paraformaldehyde/PBS for $15 \mathrm{~min}$ at room temperature before being cryo-protected by immersion in $30 \%$ sucrose/PBS overnight at $4^{\circ} \mathrm{C}$. Tissues were embedded 
using OCT and snap frozen on dry ice before being cryosectioned. $10 \mu \mathrm{m}$ sections were cut and thaw mounted onto Superfrost Plus slides. Sections were treated with $1 \%$ Triton X-100/PBS for $10 \mathrm{~min}$ at room temperature, washed in PBS and then blocked in 2\% BSA/PBS for $1 \mathrm{~h}$ at room temperature. Sections were incubated overnight at $4^{\circ} \mathrm{C}$ with the following primary antibodies diluted in $1 \%$ BSA/PBS: rabbit anti-chicken FOXL2 (in house, 1:8000, see below), rabbit anti-chicken aromatase (in house, 1:6000), rabbit anti-SOX9 (Millipore, 1:6000), goat anti-AMH (Santa Cruz, 1:1000), mouse anti-fibronectin (Serotec, 1:500), rabbit anti-P27 (Charles River Laboratories, 1;1000), rat anti-ER $\alpha(\mathrm{H} 222 ; 1: 1000)$ and anti-chicken DMRT1 (in house 1:1000). Secondary antibodies were from Invitrogen (Alexa-Fluor 488-conjugated goat antirabbit, Alexa-Fluor 594-conjugated goat anti-mouse, Alexa-Fluor 488-conjugated donkey anti-rabbit, AlexaFluor 594-conjugated donkey anti-mouse). Sections were counterstained with DAPI, mounted with Fluorosave and images were collected on a Zeiss LSM compound microscope equipped with fluorescent optics.

Anti-chicken FOXL2 antibody was raised in house by immunising a rabbit against a 'Y peptide'. This peptide comprised a synthetic 18 amino acid sequence comprising the $\mathrm{N}$ - and C-terminal regions of chicken FOXL2 joined by a with a cysteine linker (Mimotopes, Victoria, Australia). High antibody titres were confirmed by ELISA and antisera was purified by affinity chromatography. To co-localise FOXL2 and aromatase by immunofluorescence (both rabbit antibodies), the Zenon-labelling kit was used. Frozen sections were first incubated with rabbit anti-FOXL2 antibody, followed by detection with Alexa-Fluor 594, then blocked, incubated with anti-aromatase antibody and then detected with the Zenon label (green), as per the manufacturer's instructions (Thermo Fisher).

\section{FOXL2 overexpression}

In ovo electroporation of the avian retroviral vector, RCASBP(A), was used to assess the effects of FOXL2 overexpression in chicken embryonic gonads. This replication-competent vector that can spread horizontally to neighbouring cells as well as vertically to daughter cells following initial infection (Cepko et al. 1998, Logan \& Tabin 1998, Harpavat \& Cepko 2006). Chicken FOXL2 open reading frame was cloned into the RCASBP(A) strain viral vector and overexpression was validated in vitro (see Fig. 1). For electroporation, high-quality $R C A S B P(A)-c F O X L 2$ DNA was prepared from overnight bacterial cultures using the Nucleobond Maxiprep kit according to the manufacturer's instructions. DNA was used at final concentration of $1 \mu \mathrm{g} / \mu \mathrm{L}$, diluted in electroporation $\operatorname{mix}(1.3 \%$ Fast Green, $0.16 \%$ carboxymethyl cellulose, $1 \mathrm{mM} \mathrm{MgCl} 2$, in PBS). For in ovo electroporation, embryos were pre-incubated at $37.4^{\circ} \mathrm{C}$ to day 2.5, equivalent to the Hamburger and Hamilton (HH) stages 14-16. A small hole was cut in the eggshell and approximately $0.3 \mu \mathrm{L}$ DNA in EP was injected into the left coelomic cavity. Electrodes were placed beneath the left underside of the embryo and dorsolaterally on the upper right side. An electric current was then applied using a BTX square electroporator under the following conditions: $40 \mathrm{~V}$, two pulses of $150 \mathrm{~ms}$ each, with a $10 \mathrm{~ms}$ pulse interval. By this method, DNA is targeted to the left coloemic epithelium overlying the left intermediate mesoderm, from which the gonad derives. Control embryos included the right un-electroporated gonad and left gonads electroporated with RCASBP(A).GFP prepared as above. Eggs were sealed with clear tape and incubation was resumed until harvesting 5 days later at E7.5-8.0 (stage 32-33). Experiments were repeated at least three times and involved at least 50 embryos for each experiment. Embryo survival was initially high (over 70\%) but declined over time to around $40 \%$ by day 7.5 . Immunostaining tissues with viral P27 antibody, which detects a viral epitope, confirmed RCASBP(A) infection in left (electroporated) gonads but not the right (non-electroporated control) gonads. The left gonad was chosen for electroporation due to the asymmetrical development of female gonads in chicken; only the left gonad develops into a functional ovary, while the right ultimately regresses.

\section{Knockdown of FOXL2 in the gonads}

RNA interference was used to knockdown endogenous FOXL2 expression in embryonic chicken gonads. Several shRNAs directed against chicken FOXL2 mRNA were designed using the Invitrogen Block-It algorithm. shRNAs were based on the commonly used loop sequence first described by Brummelkamp et al. (5'-UUCAAGAGA-3') (Brummelkamp et al. 2002). The several chosen shRNAs were separately cloned downstream of a chicken U6-4 POL III promoter in pSLAX shuttle plasmid. ClaI fragments containing the U6.FOXL2-shRNA were subcloned into the ClaI site of RCASBP(A) viral vector. These RCASBP(A).FOXL2.shRNA constructs were firstly tested in chicken DF1 cells co-transfected with FOXL2. One shRNA showing robust FOXL2 knockdown (over $85 \%$ by immunofluorescence) was chosen for functional 
A Western blot

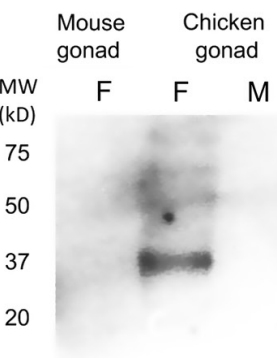

10
B FOXL2 protein over-expression in vitro

Untransfected cells

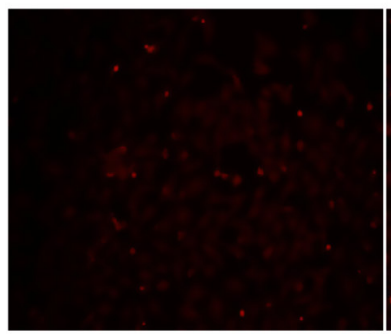

+ RCASBP-FOXL2

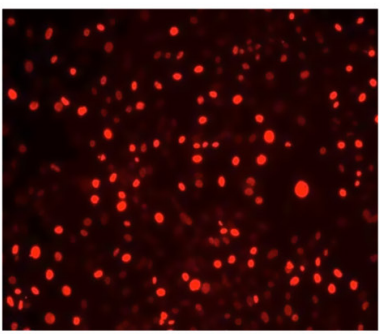

C FOXL2 protein expression in vivo

D Antibody Readsorption

FOXL2 / Fibronectin
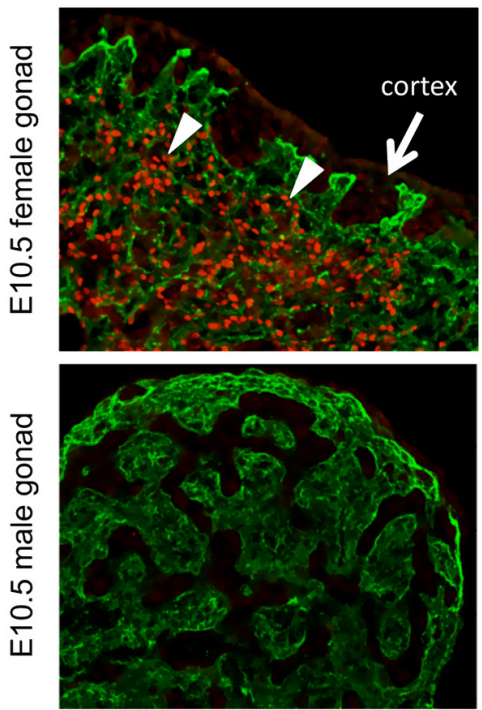

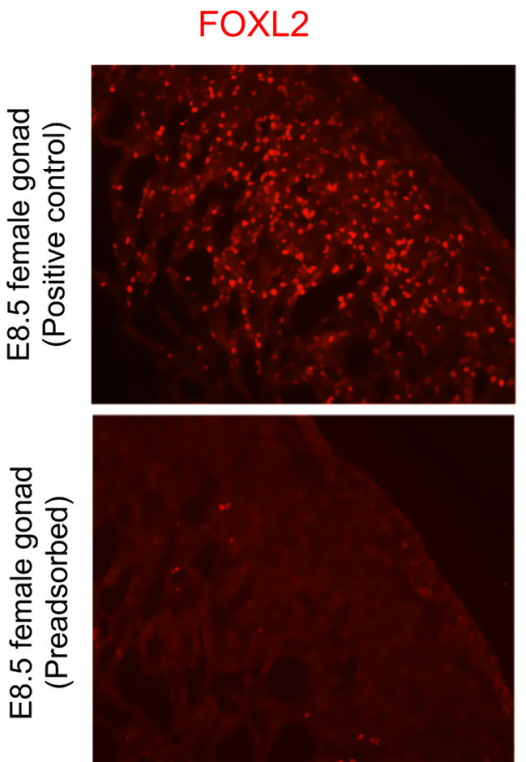

Figure 1

Validation of anti-chicken FOXL2 antibody. (A) Western blotting detects a single $37 \mathrm{kDa}$ band in day 10.5 female but not male embryonic chicken gonads. It does not detect mouse FOXL2. (B) Immunofluorescent detection of nuclear-localised CFOXL2 protein in DF1 cells relative to un-transfected cells. Cells were transfected with RCASBP(A) viral vector expressing the chicken FOXL2 CDNA. (C) Detection of FOXL2 protein in vivo. E10.5 (HH stage 36 embryonic chicken gonads. FOXL2 is detected in the medullary cells of female gonads (red) but not in males. Sections counterstained for fibronectin (green). (D) Antibody pre-adsorption text. Expression of FOXL2 in E8.5 female gonads (red) is abolished when antibody is pre-incubated with $100 \times$ molar excess antigen (FOXL2 Y peptide). studies in ovo. This was shRNA689: 5' GCAGTTGGCAC T G G C A T G G T G A A C T C C T A C A A T A C C A T C T G C T G C T T C A C T A T T G T A G G A G T T C A C C A T G C C A A C G C T C A C T G T C A A C A G CAATA-3' (sense-loop-antisense).

\section{Results}

\section{Validation of a chicken FOXL2-specific antibody}

A rabbit polyclonal antibody was raised against chicken FOXL2, using an 18 amino acid Y peptide immunogen from the $\mathrm{N}$ - and C-termini of the cFOXL2. Following immunisation and collection of sera, the antibody was affinity purified. By Western blotting, this antibody recognised a $37 \mathrm{kD}$ protein in E10.5 female but not male embryonic chicken gonads (and not in female mouse gonads) (Fig. 1A). The antibody also gave positive immunofluorescent results when the RCASBP(A) viral vector was used to overexpress FOXL2 open reading frame in chicken DF1-transformed fibroblastic cells (Fig. 1B and C). The antibody was then tested on E10.5 embryonic chicken gonads. It detected nuclear FOXL2 in the medullary cord cells of female gonads but not in male gonads. Pre-adsorption of the antibody with $100 \times$ molar excess FOXL2 peptide used for immunisation abolished specific staining (Fig. 1D). These experiments showed that the rabbit FOXL2 antibody specifically detected chicken FOXL2 protein in vitro and in vivo.

\section{Female-specific expression of cFOXL2 in embryonic chicken gonads}

In the chicken embryo, the gonads develop on the ventromedial surface of the mesonephros (embryonic kidneys). Gonads are morphologically undifferentiated at embryonic day (E) 4.5 (stage 25). At this stage, 
gonads are considered morphologically 'bipotential' or 'indifferent'. Gonadal sex differentiation commences at the histological level from E6.5 (stage 30) and is advanced by E8.5 (stage 33-34) (Smith \& Sinclair 2004). Males develop seminiferous cords while females develop a thickened outer cortex, and the inner tissue (medulla) becomes fragmented. We previously conducted RNA sequencing of female and male blastoderms and early embryonic chicken gonads at E4.5 (stage 25) and E6.0 (stage 29) (Ayers et al. 2013). RNA-seq showed that FOXL2 mRNA expression was negligible in blastoderms (FPKM in females of 1.9, 1.3 in males) (Fig. 2A). Expression was sexually dimorphic in 'bipotential' E4.5 gonads, being elevated in females (female FPKM $=6.0$, male $=0.9, P$ value $8.47 \mathrm{E}-22$ ). Female-specific expression became marked in E6.0 gonads, just prior to sexual differentiation (female $=44$, males $=0.9, P$ value 1.94E-78) (Fig. 2A). Thus, FOXL2 transcripts can be detected female specifically as early as E4.5, prior to the onset of gonadal sex differentiation, which begins histologically at E6.5 (stage 30). Using less-sensitive methods, previous studies have also reported female-specific FOXL2 expression in embryonic chicken gonads (Loffler et al. 2003, Hudson et al. 2005). However, a fine time course analysis of chicken FOXL2 protein expression has not previously been performed. Here, urogenital systems were examined at days 4.5 (stage 25), 5.0 (stage 27), 5.5 (stage 28), 6.0 (stage 29) and 7.0 (stage 31-32). The protein was only detected in developing ovaries, with no immunostaining detected in males (see Fig. 1). In females, FOXL2 protein was first detected at E5.5 (stage 28), 1 day after the transcript was detected by RNA-seq. FOXL2 protein continued to be expressed throughout female gonadal sex differentiation (E6.0-E7.0; stage 30-32; Fig. 2B). For comparison, aromatase enzyme expression was also examined. Aromatase was also restricted to the somatic cells of the medullary cords in female embryos and was first observed at E6.0 (stage 29), approximately $12 \mathrm{~h}$ after the onset of FOXL2 expression (day 5.5, stage 27-28) (Fig. 2B). Similar to FOXL2, femalespecific aromatase expression was observed throughout all subsequent developmental stages examined. Hence, the temporal expression pattern of FOXL2 just prior to aromatase makes it a candidate regulator of the enzyme.

To analyse the spatial relationship between FOXL2 and oestrogen synthesis, double staining was carried out. During early stages of ovarian development (up to E8.5; stage 33-34), FOXL2 expression was localised to the nuclei of medullary cord cells, with no expression detected in the overlying cortex (Fig. 2B). At these stages,

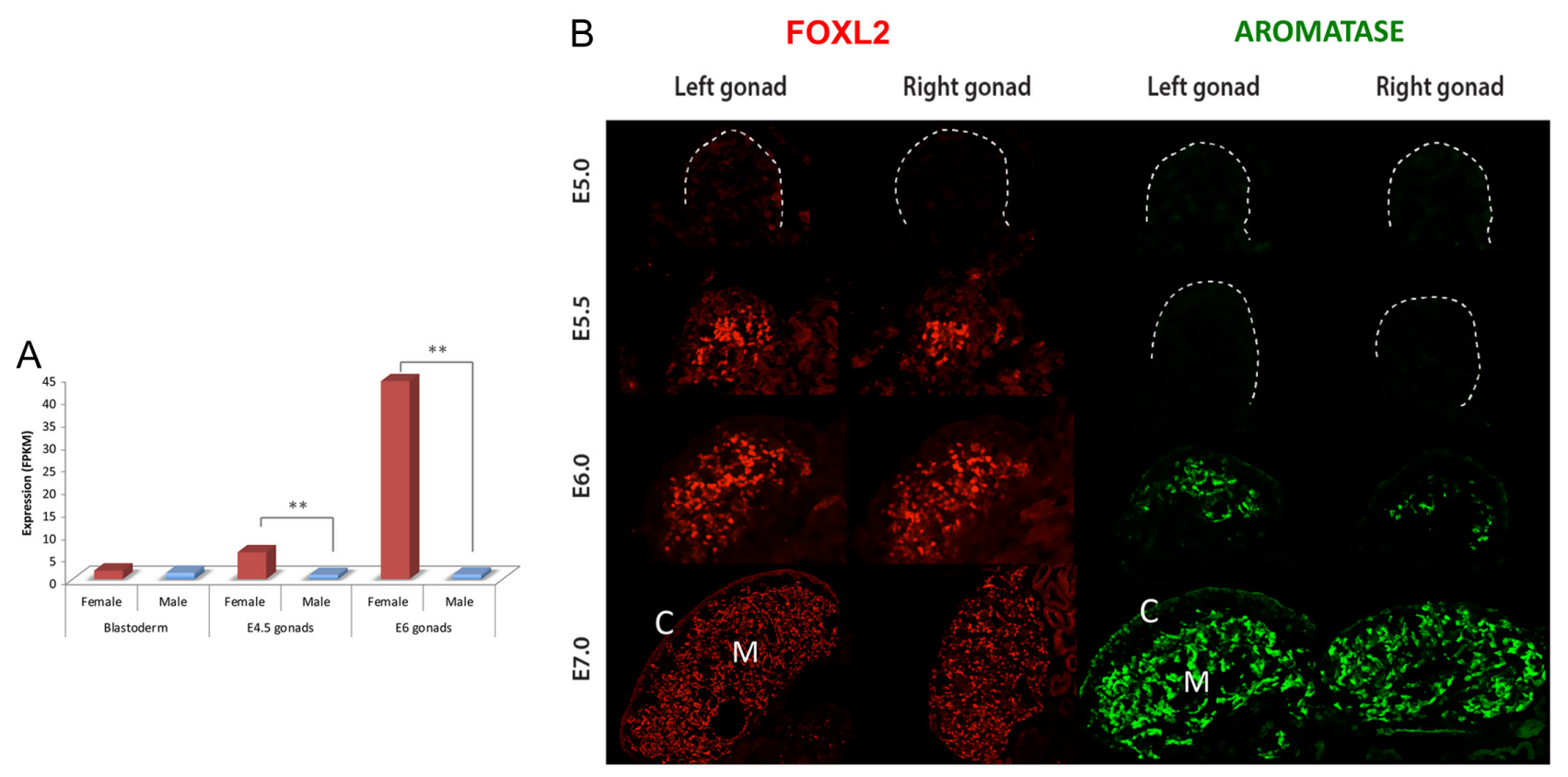

Figure 2

FOXL2 mRNA and protein expression in the chicken embryonic gonads. (A) RNA sequencing data reveal FOXL2 transcripts as early at E4.5 (stage 25 ) in female gonads. This expression increases in E6 (stage 29) gonads. ( $* * P<0.01$ ). (B) CFOXL2 and aromatase expression during gonadal sex differentiation in female embryonic chicken gonads, determined by immunofluorescence. FOXL2 is first detected at E5.5 (HH stage 28 ) in the nuclei of medullary cord cells. Aromatase (shown in green) is also sexually dimorphic and is also observed in the medullary cord cells, from E6.0 (HH stage 29 ). Both genes are expressed in the left and right gonads of females. Expression is observed the medulla (M) and not the cortex (C). $10 \mu \mathrm{m}$ transverse sections. 
FOXL2 and aromatase proteins were mostly co-localised in the same medullary cord cells (Fig. 3A). This co-location was maintained up to at least E14.5 (stage 38), when the ovary is well developed and cortical germ cell meiosis begins (Fig. 3A). However, at both of these stages, small numbers of medullary cord cells were detected that did not co-express the two proteins. These cells were either only FOXL2+ or only aromatase+ (Fig. 3A). Interestingly, co-staining for FOXL2 and the basement membrane marker, fibronectin, revealed a sub-population of cortical cells highly expressing FOXL2 at E14.5 (Fig. 3B). As FOX proteins can be obligate co-factors for estrogen receptor- $\alpha$ (ER $\alpha)$ (Kim et al. 2009), and ER $\alpha$ is expressed in the ovarian cortex, double staining was carried out. This showed that the cortical cells expressing FOXL2 and those expressing $\mathrm{ER} \alpha$ were mutually exclusive (Fig. 3C).

\section{Targeted misexpression of cFOXL2 suppresses testis pathway genes}

The medullary cords of the embryonic gonads play a key role in avian sexual differentiation. In males, they are the site of Sertoli cell differentiation. In females, they produce the oestrogen that is required for ovarian development (Scheib 1983, Vaillant et al. 2003, Lambeth et al. 2016). Given the early expression profile of FOXL2 in the key medullary cord cell lineage, this protein may play an important role

\section{A E8.5 Female gonad (medulla)}

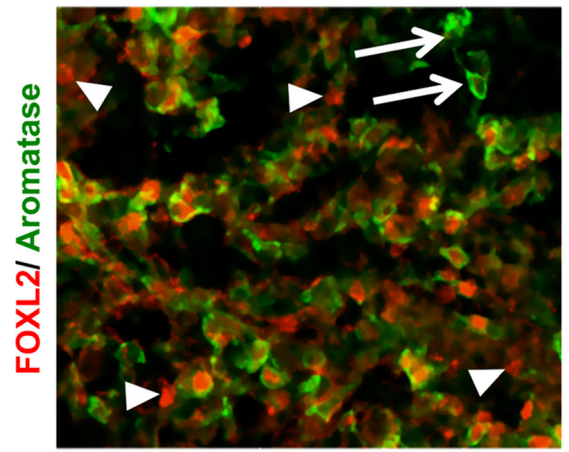

B

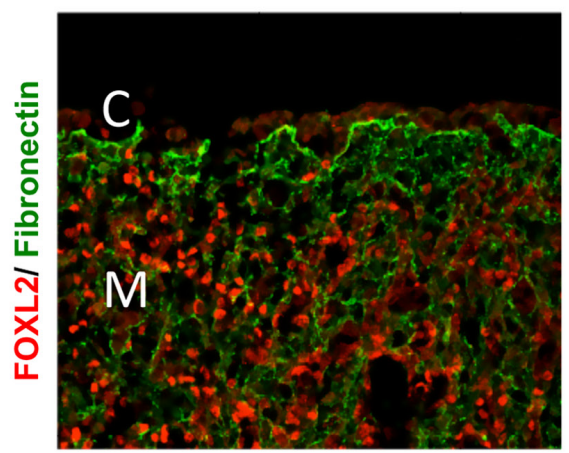

C

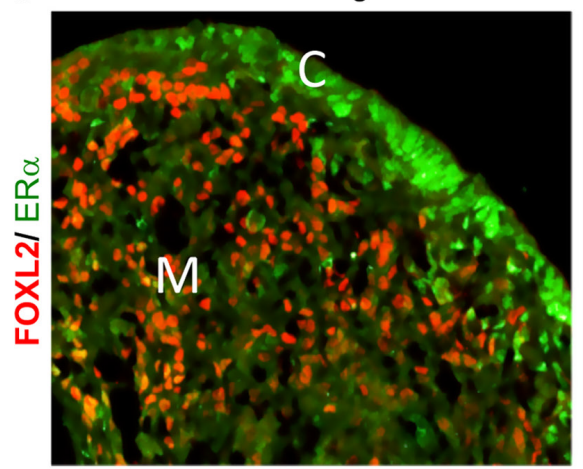

E14.5 Female gonad (medulla)

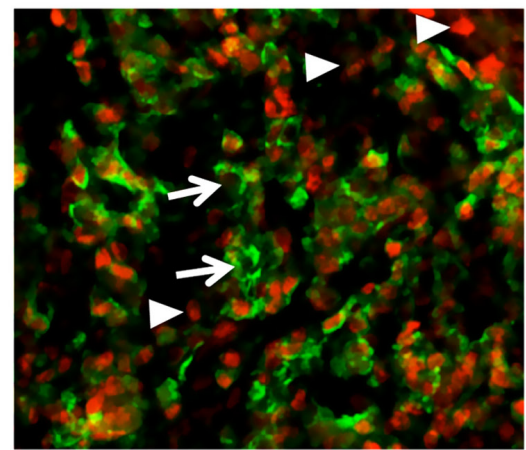

E14.5 Female gonad

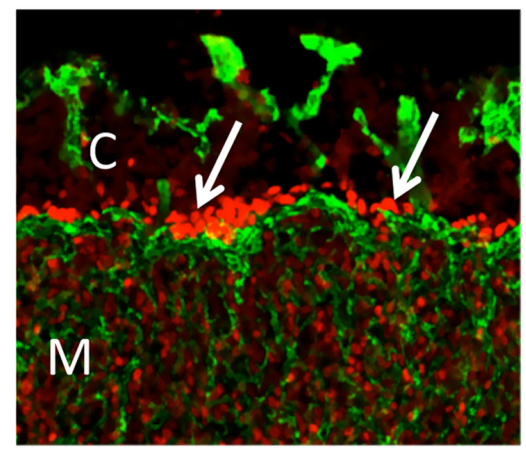

E14.5 Female gonad

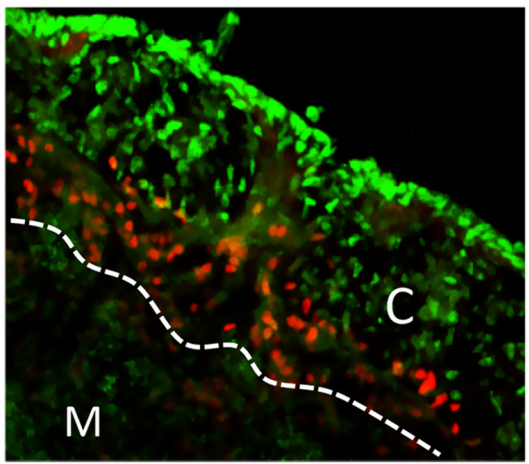

\section{Figure 3}

Expression of FOXL2, aromatase and oestrogen receptor alpha in ovaries. (A) Co-localisation of FOXL2 and aromatase proteins in the ovarian medulla of the E8.5 (st34) and E14.5 (st 38) chicken ovary. FOXL2 (red) is expressed in the nuclei of medullary cord cells and aromatase is expressed in the cytoplasm of the same cells (green). At both time points, some cells express only FOXL2 (arrowheads) or only aromatase (arrows). (B) CFOXL2 (red) is expressed in medullary cord cells of the female embryonic gonad at E8.5. Fibronectin (green) delineates the outer cortex $(C)$ and the inner medulla $(M)$. In E14.5 gonads, a number of cortical cells arranged along the basement membrane now strongly express FOXL2 (arrows). $10 \mu \mathrm{m}$ transverse sections. (C) FOXL2 does not co-localise with cortical ERa. At E8.5 (st 34), ER $\alpha$ protein is detected in the developing cortex, while FOXL2 is present in the medulla. At E14.5 (st 38), when FOXL2 (red) is detectable in the cortex (C), it does not localise with ER $\alpha$ (green). (M, medulla). https://joe.bioscientifica.com https://doi.org/10.1530/JOE-19-0277 (c) 2019 Society for Endocrinology Published by Bioscientifica Ltd. Printed in Great Britain 
in sexual differentiation of the embryonic ovary in the chicken. The expression patterns of cFOXL2 and aromatase suggest that the former regulates the expression of the latter. Furthermore, studies in other vertebrate species have shown that FOXL2 can antagonise the male developmental pathway (Veitia 2010, Elzaiat et al. 2014). This has not been demonstrated in birds. In order to further explore the role of cFOXL2 in chicken gonadal sex differentiation, misexpression in males and knockdown in females were performed. Firstly, for misexpression, the chicken FOXL2 open reading frame was cloned into the RCASBP(A) avian retroviral vector. This viral vector infects and spreads across avian cells, constitutively expressing a gene of interest from its long terminal repeat (LTR) promoter. Efficient expression of FOXL2 from this vector was confirmed by transfecting chicken DF1 cell in culture (see Fig. 1B). FOXL2-expressing proviral DNA was electroporated into the left coelomic cavity of E2.5 embryos (HH stage 14). This method targets the left coelomic epithelium overlying the intermediate mesoderm, from which the gonad derives. We have previously used this technique to show that DMRT1 overexpression causes female-to-male sex reversal of the gonads (Smith et al. 2009a). Experimentally manipulated embryos were incubated for 5 days post electroporation and examined at E8 (HH stage 33). Embryos were sexed by PCR and sectioned longitudinally before being analysed by immunofluorescence.

Controls for misexpression included the right nonelectroporated gonads and left presumptive gonads electroporated with virus expressing GFP. In control male embryos electroporated with viral DNA expressing GFP, the gonads develop normally, expressing AMH but not FOXL2 nor aromatase (Fig. 4A). In control females expressing GFP, FOXL2 and aromatase are expressed, but not AMH of SOX9 (Fig. 4B). The effects of FOXL2 misexpression were examined in genetically male embryos, which do not ordinarily express the gene. Electroporation resulted in variable delivery of FOXL2 into male gonads. At day 8 (stage 33) P27 immunostaining revealed the spread of the viral vector, and this corresponded to the extent of FOXL2 delivery. An example is shown in Fig. 4, in which the posterior part of the male gonad exhibited P27 expression that correlated with FOXL2 misexpression (Fig. 4A and B). In these male gonads, double staining revealed that regions of the gonad misexpressing FOXL2 lost AMH expression, a marker of developing Sertoli cells (Fig. 4C). Further analysis of FOXL2 misexpression is shown in Fig. 5. In control male gonads examined at E8 (embryos electroporated with empty RCASBP(A) virus or virus expressing GFP), FOXL2 was not expressed (Fig. 5A).
Developing control testes showed a network of seminiferous cords, surrounded by the extracellular matrix marker, fibronectin (Fig. 5B). Sertoli cell markers SOX9, AMH and DMRT1 were expressed in the control males, while germ cells were distributed throughout the gonad, as assessed by expression of Chicken Vasa Homologue (CVH) (Fig. 5C, D and E). In contrast, in E8 male gonads misexpressing FOXL2, the male pathway was blocked and Sertoli cell differentiation was disrupted. In the images shown in Fig. 5, widespread delivery of FOXL2 was achieved in the posterior part of the gonad, while a more anterior region shows less FOXL2 misexpression (Fig. 5F; arrow vs arrowhead). Fibronectin delineated a typical network of testis-type cords at the anterior pole (where less FOXL2 was delivered), while cord organisation was disrupted more posteriorly (Fig. 5G, arrowhead vs arrow). Sertoli cell markers SOX9, AMH and DMRT1 were also expressed normally at the anterior pole, but were absent in the posterior region misexpressing FOXL2 (Fig. $5 \mathrm{H}$ and I). However, there were parts of the gonad where SOX9/AMH was lost, but DMRT1 expression persisted (Fig. 5I, asterisks). Overall, this result indicates a loss of Sertoli cell differentiation where FOXL2 was present. Furthermore, CVH expression was lost in those regions of the mis-expressing FOXL2 (Fig. 5J). DAPI staining showed that cells were still present in male gonads misexpressing FOXL2 (Fig. 6A and B). Despite the presence of gonadal cells, Sertoli cells were not present, as shown by loss of AMH and DMRT1 in the precise location of FOXL2 misexpression (Fig. 6A, B, C and D; bracket). However, misexpression of FOXL2 in male gonads did not activate ectopic aromatase expression (Fig. 6E). Overexpression of FOXL2 in ovaries had no effect on female markers such as aromatase (not shown). Thus, FOXL2 misexpression blocked the male pathway, but appeared not to activate the female pathway, in genetic male gonads. In female gonads, where FOXL2 is typically expressed, overexpression of the gene had no overt effect (data not shown).

\section{RNAi-mediated knockdown of FOXL2 leads to ectopic SOX9 expression in females}

As complementary approach to studying the effects of FOXL2 overexpression in males, shRNAs were designed and tested for FOXL2 knockdown in females. Several shRNAs directed against regions of the chicken FOXL2 open reading frame were cloned into the RCASBP(A) viral vector and tested independently in vitro using chicken DF1 fibroblasts. Viral vectors expressing the shRNAs were co-transfected with a virus expressing FOXL2. 

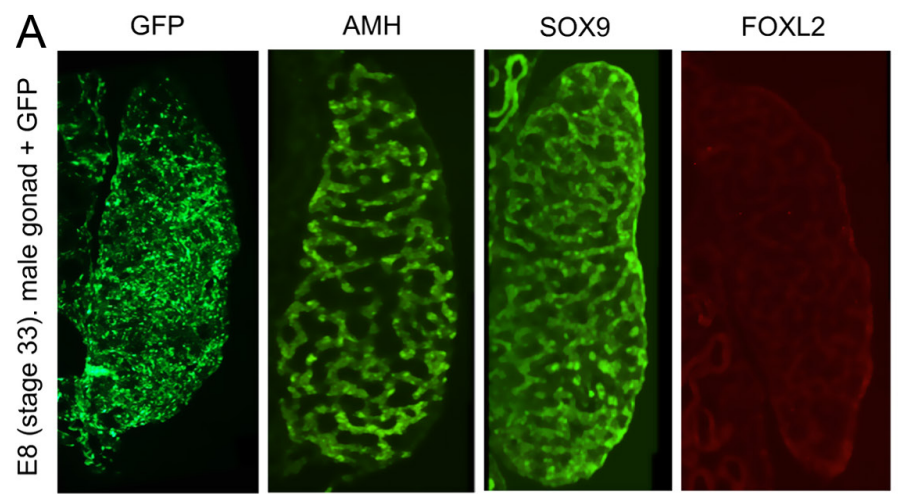

AROMATASE

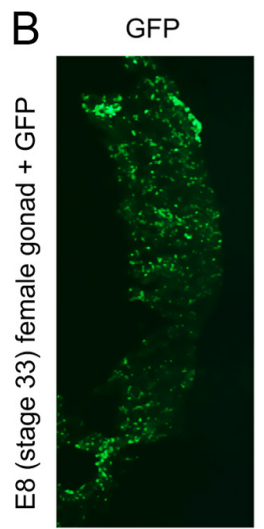

$\mathrm{AMH}$
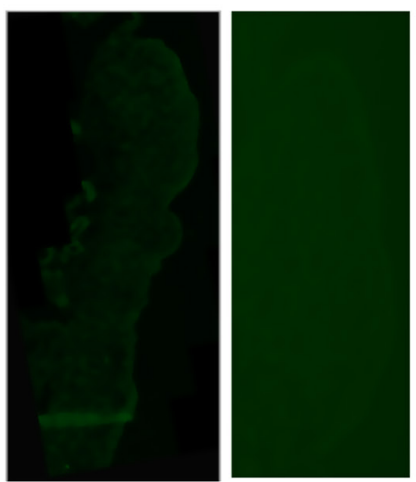

FOXL2

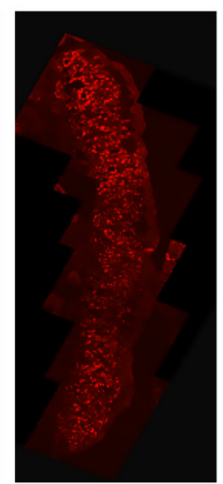

\section{P27 (Virus)}
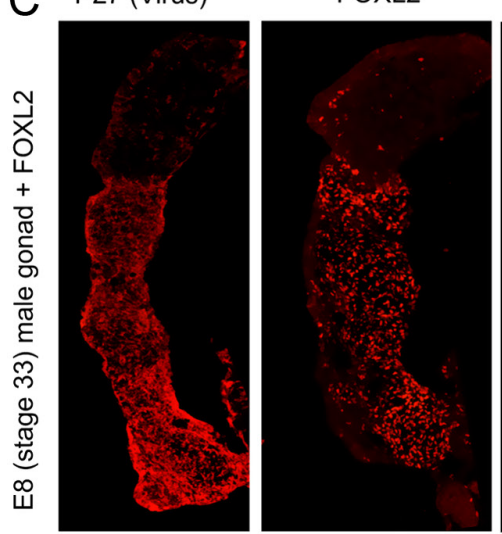

FOXL2 /AMH

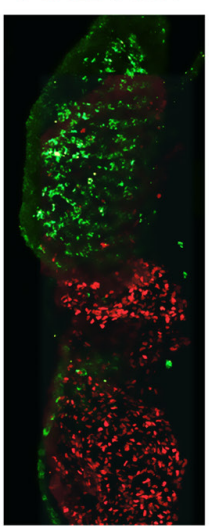

Cells transfected with non-silencing control shRNAs showed robust FOXL2 expression (Fig. 7A and B). Cells transfected with FOXL2-shRNA\#689 showed significant reduction in expression after 1 week in culture (Fig. 7C and D). Several other shRNAs showed no or variable knockdown. FOXL2-shRNA\#689 was then used for in vivo studies. High titre recombinant virus was purified and injected into day 0 blastoderms, to ensure widespread infection. Embryos were dissected at day 8 (stage 33) and processed for immunofluorescence.

Results of the knockdown experiments are shown in Fig. 8. P27 staining demonstrated robust viral spread in gonads subjected to either shRNA knockdown or

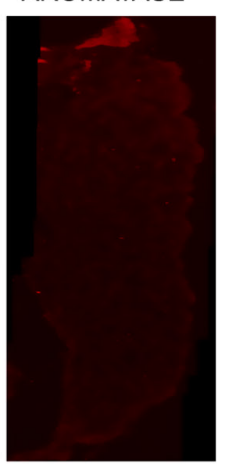

\section{AROMATASE}

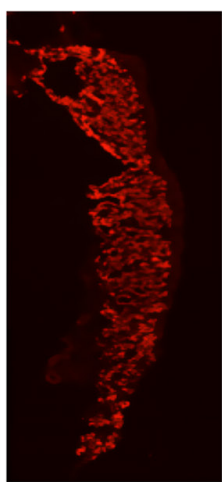

\section{Figure 4}

Misexpression of FOXL2 in embryonic chicken gonads. (A) E8 (HH stage 33) control male left gonad electroporated with RCASBP(A) virus expressing GFP. Widespread GFP is present, together with $\mathrm{AMH}$ and SOX9 expression in organising seminiferous cords. No FOXL2 or aromatase expression. Longitudinal sections are shown. (B) E8 (HH stage 33) control female left gonad electroporated with RCASBP(A) virus expressing GFP. Widespread GFP is present, and no detectable AMH or SOX9 protein. FOXL2 and aromatase are expressed. Longitudinal sections are shown. (C) Spread of RCASBP(A) viral vector across posterior but not anterior regions of an E8 (HH stage 33) male left gonad, as shown by P27 viral epitope staining. In this gonad,

misexpression of FOXL2 in the nuclei of cells is observed. Immunofluorescent co-staining shows loss of AMH expression (green) in those parts of the gonad expressing FOXL2 (red). Longitudinal sections are shown.

non-silencing shRNA (control) (Fig. 8A, B and C). In embryos infected with RCASBP(A).FOXL2.shRNA\#689, there was a loss of FOXL2 expression in female gonads at E8, relative to controls, in which FOXL2 was expressed female specifically (Fig. 8D, E and F). Surprisingly, there was no corresponding loss of aromatase expression relative to control females (Fig. 8G, H and I). However, ectopic activation of SOX9 was observed following FOXL2 knockdown, relative to females controls that do not express the male marker (Fig. 8J, K and L, arrows). This ectopic SOX9 expression was not organised into cords, and indeed knockdown gonads appeared ovo testicular or partly sex reversed. This was reflected in the expression 
FOXL2
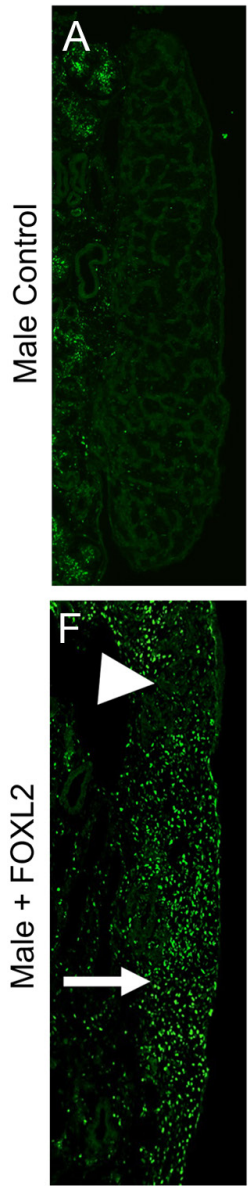

Fibronectin
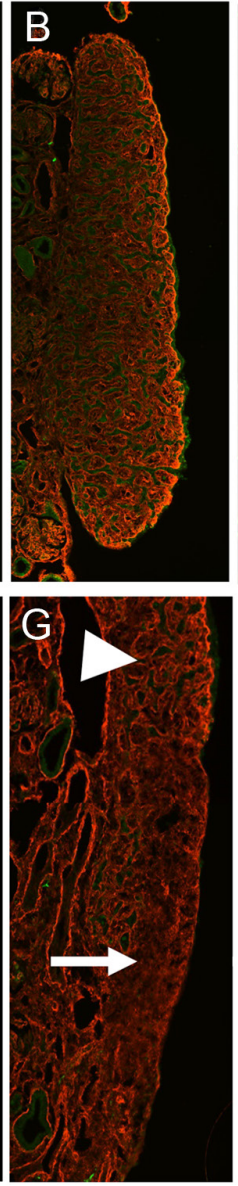

SOX9/AMH
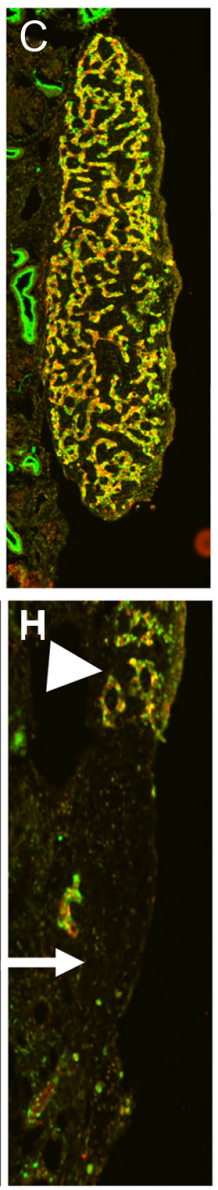

DMRT1
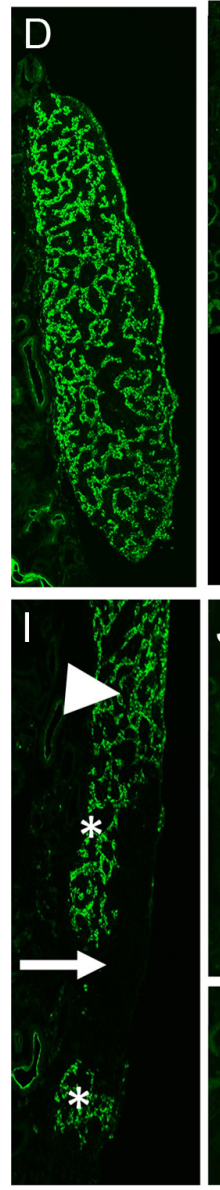

Germ cells
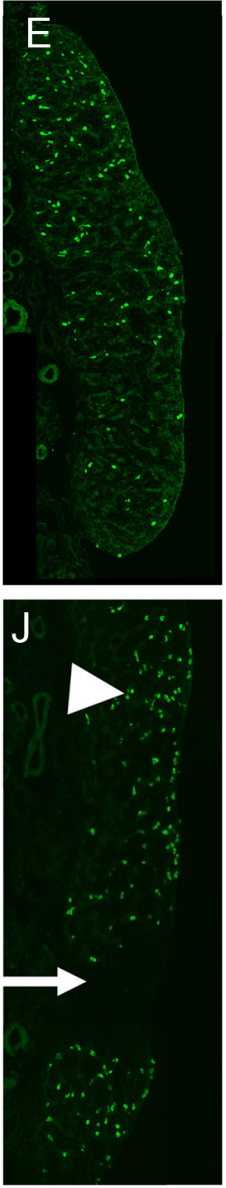

\section{Figure 5}

Loss of Sertoli cells and male pathway markers in male gonads mis-expressing FOXL2. (A) Embryonic day 8 (HH stage 33) control male gonad lacking FOXL2 expression. (B) Control male gonad showing a network of seminiferous cords, delineated by fibronection expression. (C) SOX9 (red) and AMH (green) expression in Sertoli cells of control male gonad. (D) DMRT1 expression in Sertoli cells of control male gonad. (E) Germ cells, as marked by $\mathrm{CVH}$ expression, in a control male gonad. (F) Day 8 (stage 33) male gonad misexpressing FOXL2 in the posterior region (arrow) but not in an anterior region (arrowhead). (G) Fibronectin staining shows disruption of normal cord organisation in areas mis-expressing FOXL2 (arrows) compared to areas not misexpressing the gene (arrowheads). (H) Male gonad misexpressing FOXL2 shows loss of SOX9 and $\mathrm{AMH}$ markers in posterior region, but not in anterior region. (I) Localised loss of DMRT1 expression in posterior region of gonad misexpressing FOXL2 (arrows) vs intact expression more anteriorly (arrowhead). In some parts of the gonad where SOX9/AMH expression was lost, DMRT1 expression persists (asterisks). (J) Localised loss of $\mathrm{CVH}$ in region of the male gonad misexpressing FOXL2. All images show $10 \mu \mathrm{m}$ longitudinal sections through a representative gonad. of AMH protein, which is expressed male-specifically in controls (Fig. 8M and N). FOXL2 knockdown in female gonads induced a modest activation of $\mathrm{AMH}$ protein, primarily in cords of cells in the outer part of the gonadal medulla (Fig. 80, arrows). In contrast to ectopic SOX9 expression, FOXL2 knockdown did not increase DMRT1 expression in female gonads. DMRT1 was highly expressed in control males and less expressed in females, except in cortical germ cells, where it was highly expressed Fig. 8P and Q.

Following FOXL2 in female gonads, DMRT1 was still less expressed, but it did delineate male-like cords in some areas of the gonad (Fig. 8R, arrows), while other deeper areas showed typically female-like lacunae (cavities) (Fig. 8R, asterisk). CVH staining showed that the germ cells in control males were arranged in the cords of the medulla, while those in control females were mainly concentrated in the developing cortex. FOXL2knockdown female gonads still developed a cortex that harboured germ cells, as assessed by CVH staining (Fig. 8S, $\mathrm{T}$ and $\mathrm{U}$, arrow). There appeared to be fewer cortical germ cells following FOXL2 knockdown versus control females (i.e., more 'male-like', (Fig. 8U asterisk), though this was not quantified. Taken together, these results indicate that FOXL2 can antagonise the male pathway at the level of SOX9 in the avian model.

\section{Discussion}

FOXL2 is a transcription factor required for proper ovarian function in vertebrates (Uhlenhaut \& Treier 2006, Georges et al. 2014, Bertho et al. 2016). However, its exact role can differ, even among mammals. While FOXL2 is expressed from embryonic day (E)12.5 in foetal mouse ovaries, targeted deletion causes granulosa cell dysfunction and impaired folliculogenesis only postnatally (Schmidt et al. 2004, Uda et al. 2004, Ottolenghi et al. 2005). For more extensive masculinisation, both Foxl2 and the R-SPO1/Wnt4/ $\beta$-catenin pathways must be inactivated in embryonic XX gonads (Ottolenghi et al. 2007). FOXL2 is subsequently required for ovarian maintenance in adult mice, such that gonads losing FOXL2 expression 
E8 (stage33) male gonad
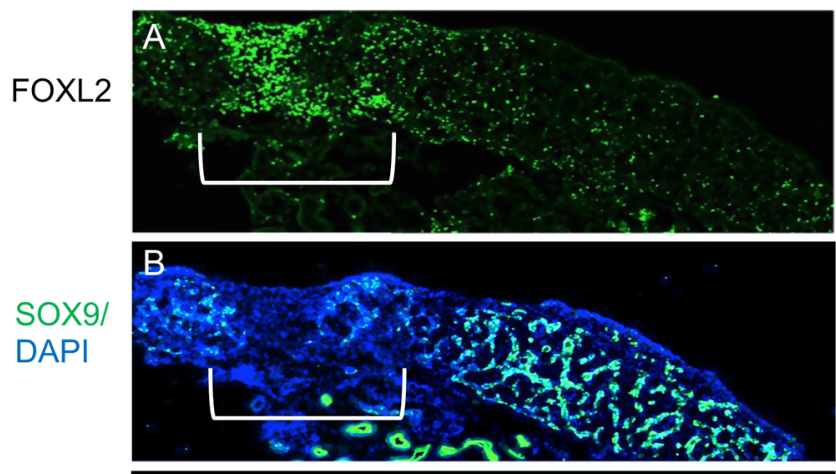

$\mathrm{AMH}$
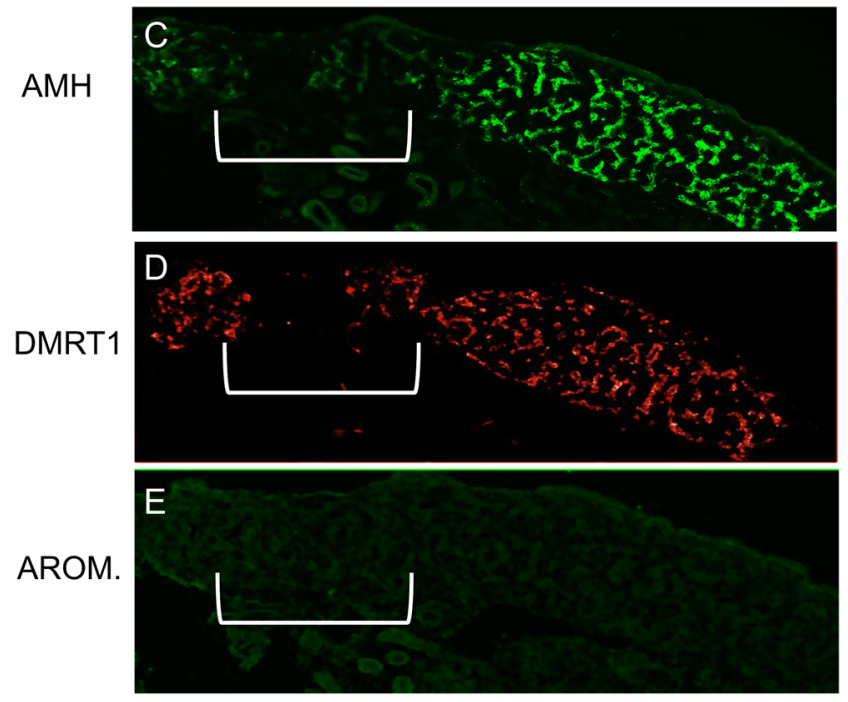

\section{Figure 6}

DAPI and aromatase staining in E8 male chicken gonads misexpressing FOXL2. (A) Localised misexpression of FOXL2 in a male gonad. (B) DAPI and SOX9 staining in same gonad as in A. DAPI reveals the presence of cells. (C) Localised loss of AMH expression and (D) localised loss of DMRT1 expression in the same gonad. (E) No ectopic expression of aromatase in male gonads misexpressing FOXL2.

are reprogrammed into testes (Uhlenhaut et al. 2009). Similarly, humans with blepharophimosis epicanthus inversus syndrome (BPES) have loss-of-function mutations in FOXL2 and exhibit post-embryonic ovarian failure (Crisponi et al. 2001, De Baere et al. 2001, De Baere et al. 2002, Harris et al. 2002). In contrast, in goat embryos, FOXL2 is a key ovary-determining gene at embryonic stages. Goats with the polled intersex syndrome (PIS) have a loss of horns and female-to-male sex reversal (Pailhoux et al. 2001, Cocquet et al. 2002). PIS is associated with the deletion of an $11.7 \mathrm{~kb}$ regulatory region upstream of the FOXL2 gene (Pannetier et al. 2012). Ablation of FOXL2 in the wild-type goat embryo results in embryonic sex reversal, in which XX gonads ectopically express male markers such as SOX9 and develop seminiferous cords (Boulanger et al. 2014). Among fishes, FOXL2 can also have a central sex-determining role. Mutations in FOXL2 can cause female-to-male sex reversal in the Nile Tilapia and the zebrafish, for example (Zhang et al. 2017). In both cases, loss of FOXL2 is correlated with a loss of sustained oestrogen synthesis/aromatase gene expression (Wang et al. 2007, Li et al. 2013, Yang et al. 2017).

Here, we provide the first functional analysis of FOXL2 in an avian species, the chicken. FOXL2 in the chicken embryo shows a conserved female-specific expression pattern, with protein first detectable in medullary cord cells prior to the onset of ovarian differentiation. Overexpression and knockdown results show that FOXL2 antagonises the male developmental pathway in the chicken model, though it alone may not be essential for aromatase expression. These data shed light on the evolution of FOXL2 and is also of significance to the poultry industry, which seeks mechanisms of modulating chicken sex determination. The RNA-seq data show that FOXL2 transcripts are already detectable in female gonads before the onset of morphological gonadal sex differentiation (E4.5; stage 25). The protein is first detectable by immunofluorescence at E5.5, just prior to aromatase and the onset of sexual differentiation. While other studies have reported chicken FOXL2 protein in the gonads (Govoroun et al. 2004), the exact onset of protein expression was not hitherto been reported. Early female-specific expression, pre-dating aromatase, implies an important role for FOXL2 in chicken ovarian development. This is consistent with a feminising role at embryonic stages postulated or proven in goat and fish embryos (Boulanger et al. 2014, Zhang et al. 2017), and in contrast to mouse and human, where FOXL2 has a role in granulosa cells after birth (Uda et al. 2004, Ottolenghi et al. 2005, Ottolenghi et al. 2007). Interestingly, after sexual differentiation of the gonads has occurred, at E14.5 we observed a population of somatic cells in the ovarian cortex that strongly expressed FOXL2 (Fig. 3). These cells did not express aromatase and they were basally aligned at the cortical-medullary junction. This has not been described in other species with distinct cortex and medulla. The cells could be migratory, having derived from the medulla, but we consider it more likely that this expression is de novo in resident cortical cells. As FOXL2 is linked to granulosa cell function in mammals, and the cortical cells are considered to give rise to follicles in chicken (Smith \& Sinclair 2004), this FOXL2 expression may be marking presumptive granulosa cells. Studies in mammals have also indicated that FOXL2 interacts with oestrogen receptor alpha (ER $($ Kim et al. 2009). However, in the embryonic chicken gonad, the two proteins do 

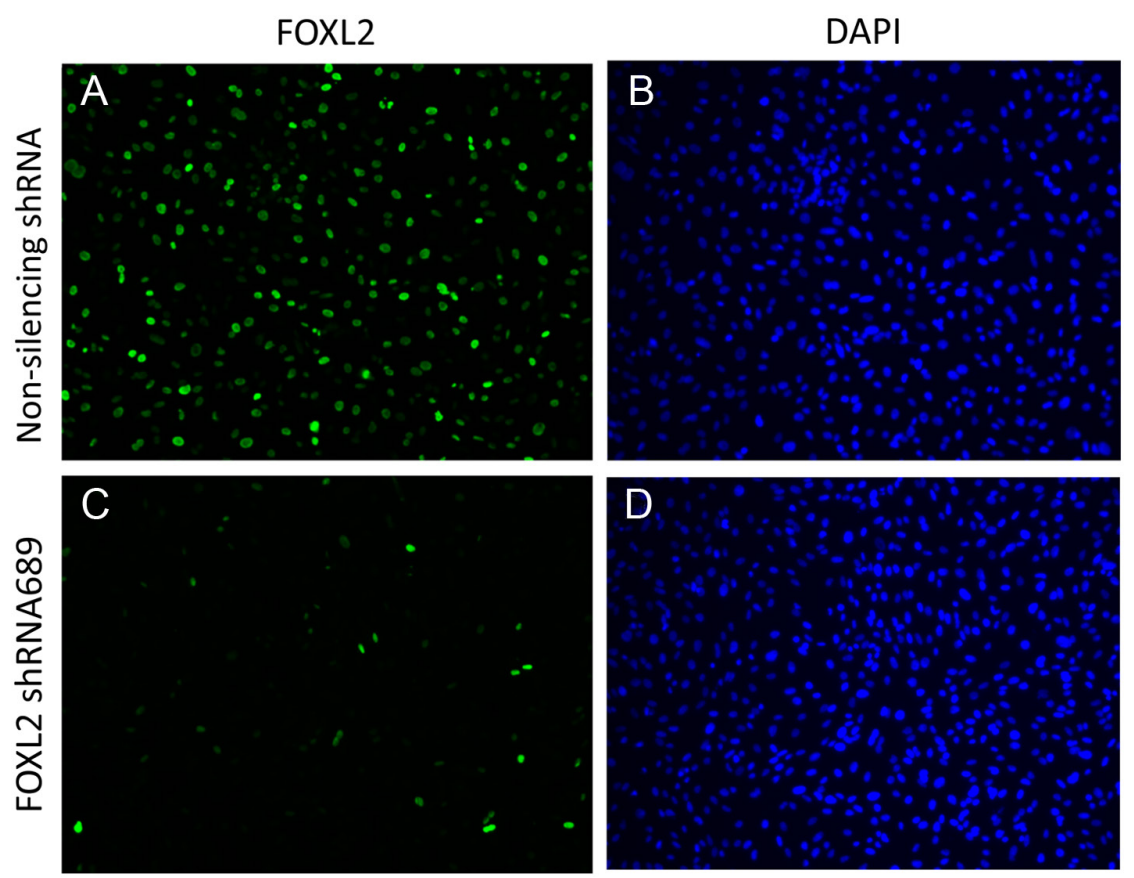

\section{Figure 7}

Knockdown of FOXL2 expression in vitro (chicken DF1 cells). (A) Control staining showing widespread expression of FOXL2 in cells infected with RCASBP (A) non-silencing shRNA and RCASBP (B) FOXL2 overexpression plasmid. (B) DAPI staining to show the cells numbers in A. (C) Cells transfected with RCASBP (A) FOXL2shRNA\#689 together with RCASBP (B) FOXL2 shows robust knockdown. (D) DAPI staining for cell numbers in $C$.

not co-localise to the same cortical cell type, precluding a direct interaction at the stages examined.

The misexpression studies show that FOXL2 can antagonise the male developmental pathway in the chicken embryo, blocking SOX9, AMH and DMRT1 expression, and preventing Sertoli cell differentiation (Figs 5 and 6). This is consistent with the anti-testis properties of FOXL2 reported in mammals (Uhlenhaut et al. 2009, Boulanger et al. 2014). Forced expression of FOXL2 in XY embryonic mouse gonads, for example, can cause disrupted testis tubule development (Ottolenghi et al. 2007). FOXL2 may antagonise the male pathway in chicken by negatively regulating DMRT1 or SOX9 expression, or both. Conversely, knockdown of FOXL2 expression in female gonads resulted in ectopic activation of SOX9 in E8 gonads, modest activation of $\mathrm{AMH}$ protein, but not upregulation of DMRT1 (Fig. 8). This is presumably due to the single dosage of Z-linked DMRT1 gene in female cells (ZW), consistent with the notion of DMRT1 dosage being important for testis development (Smith et al. 2009a). However, FOXL2 misexpression was capable of blocking DMRT1 expression in males. FOXL2 may antagonise the male pathway at the level of SOX9 in the embryonic chicken gonad. Similarly, in adult mouse, Foxl2 plays a role in direct repression at the Sox9 enhancer and loss of Foxl2 leads to prompt upregulation of Sox 9 and gonadal masculinisation (Uhlenhaut et al. 2009). Furthermore, Nicol et al. (2018) recently noted extensive overlap between FOXL2 and SOX9 occupancy across multiple enhancers, implying competition between these female- and male-promoting factors in the developing gonads (Nicol et al. 2018). This may also apply in chicken, as FOXL2 and SOX9 are expressed in the same cell lineage in females and males (medullary cord cells) and the two proteins never co-localise. If the primary function of FOXL2 in chicken is repression of SOX9 expression, then this may feedback to also repress DMRT1, as this factor was repressed after ectopic FOXL2 expression in males.

The male gonadal tissue showing a loss of DMRT1, SOX9 and AMH expression after ectopic expression of FOXL2 may be undifferentiated or it may be sexreversed (ovarian), although aromatase was not activated. We do not have a suitable marker that specifically labels undifferentiated chicken gonads, as opposed to differentiating tissue. Some markers, such as SF1 and GATA4, are expressed at undifferentiated stages, but their expression is maintained thereafter. Although seminiferous cord formation was clearly blocked, we cannot conclude as yet that ectopic FOXL2 can cause 'gonadal sex reversal' in the chicken model. Interestingly, we noted a loss of germ cells in those regions of the male gonad ectopically expressing FOXL2, as assessed by VASA staining. This was not simply a loss of VASA expression, as DAPI staining also showed a loss of germ cells. (Germ cells are readily identified by their large nuclei.) We have previously shown that germ cells silence the RCASBP viral vector (Smith et al. 2009b), so the effects of ectopic 

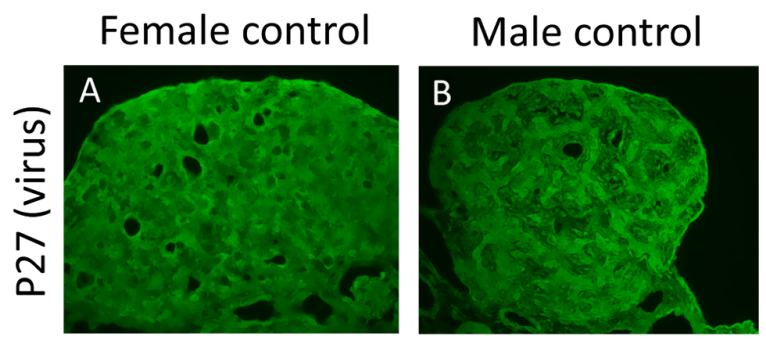

$$
\text { Female + FOXL2 KD }
$$
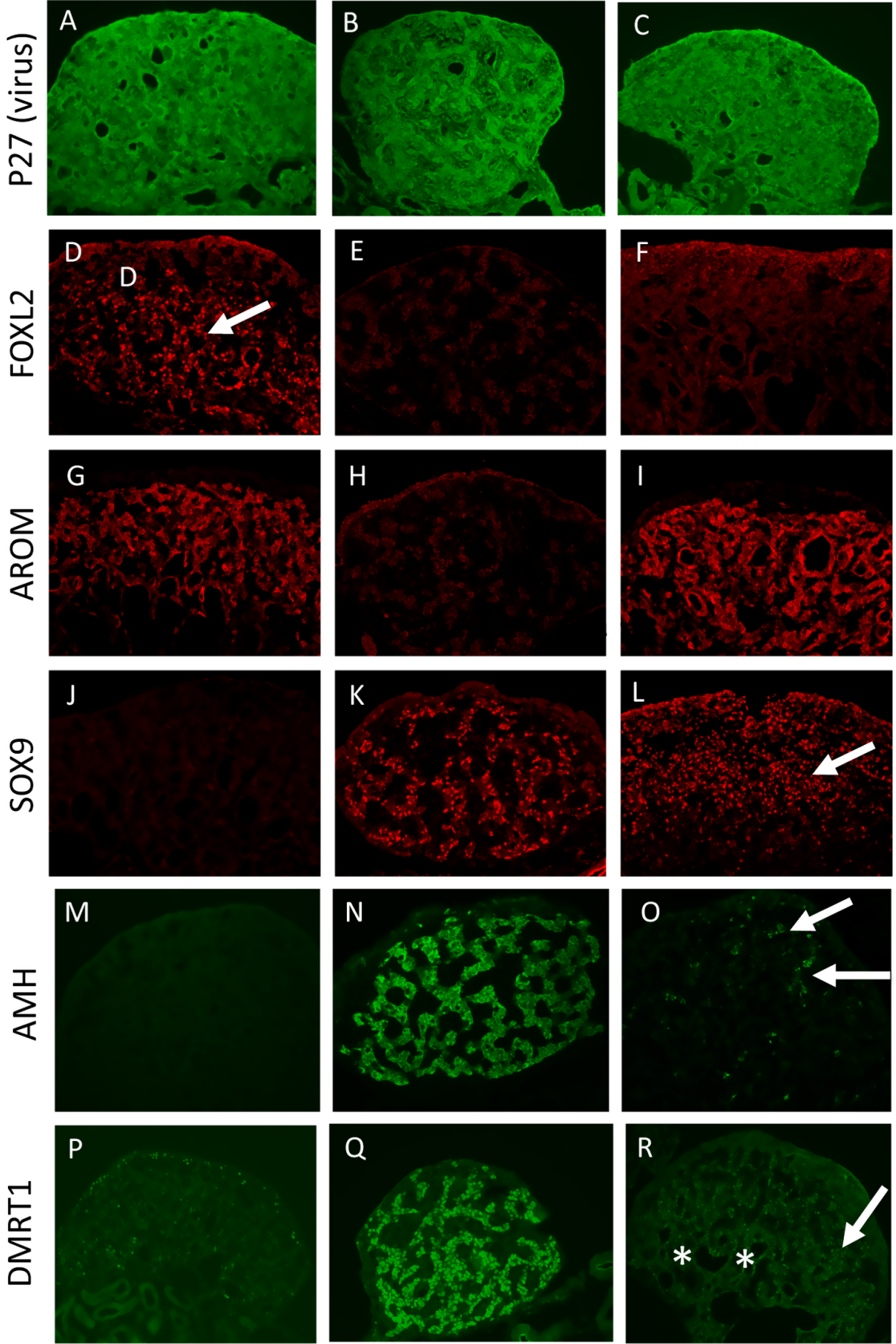

Figure 8

RNAi-mediated knockdown of FOXL2 in vivo. Immunofluorescent staining of E8 (stage 33) embryonic chicken gonads following infection with RCASBP viral vectors at E2.5. (stage 16). P27 staining shows viral delivery to gonads in non-silencing female and male control and FOXL2. sh689 knockdown gonads ( $A, B$ and C). FOXL2 is expressed in female but not male gonads and expression is lost in female gonads subjected to
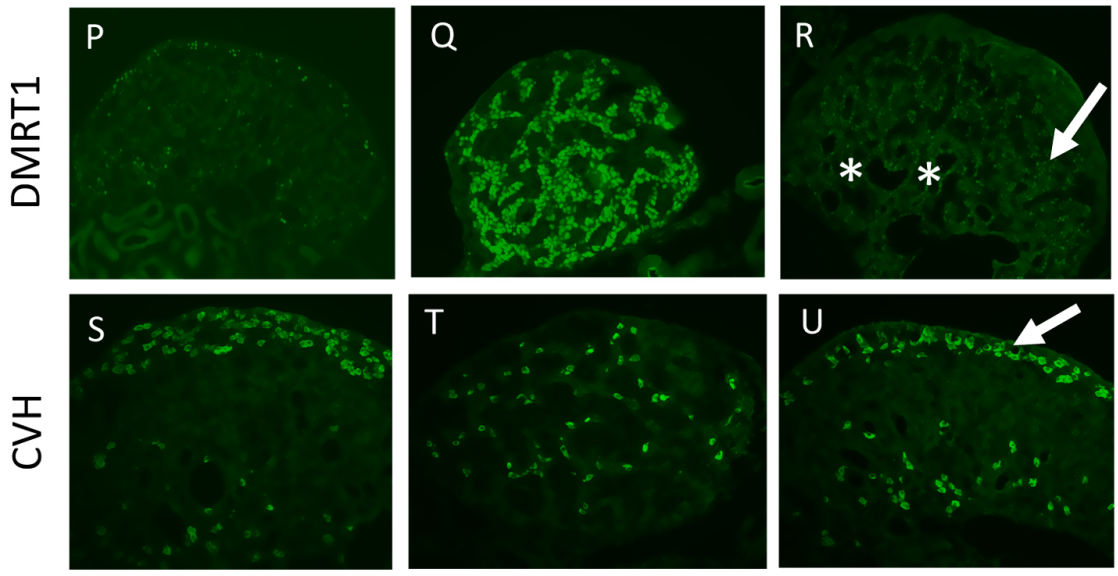
shRNA\#689 (D arrows, E and F). Female but not male control gonads express aromatase, and expression persisted in FOXL2 knockdown female gonads ( $G, H$ and I). SOX9 is expressed in male but not female controls and is widely ectopically activated in females following FOXL2 knockdown $(\mathrm{L}$, arrow). $\mathrm{AMH}$ protein is highly expressed in male controls but not in females and was activated in patches in females following FOXL2 knockdown ( $\mathrm{P}, \mathrm{Q}, \mathrm{R}$, arrow). CVH staining revealed mainly cortical germ cells in control females, medullary localised germ cells in control male, and mainly cortical germ cells in females following FOXL2 knockdown (S, T and U). There appeared to be fewer germ cells located in the cortex after knockdown compared to control ( $U$, arrow). For all images, $10 \mu \mathrm{m}$ transverse sections are shown.

FOXL2 on PGCs must be indirect, via the somatic cells. It seems likely that the loss of cord structure after FOXL2 misexpression could cause atretic loss of germ cells outside the cord environment.

\begin{tabular}{|lr}
\hline $\begin{array}{l}\text { https://joe.bioscientifica.com } \\
\text { https://doi.org/10.1530/JOE-19-0277 }\end{array}$ & (C) 2019 Society for Endocrinology \\
Published by Bioscientifica Ltd. \\
Printed in Great Britain
\end{tabular}

The data indicate that FOXL2 expression in the medullary cord cells can redirect the fate of these cells from the Sertoli lineage in male gonads in the chicken embryo. In this regard, the role of FOXL2 in the chicken is 
more aligned with that reported in fish and goat embryos, where the gene has an early gonadal sex-determining role (Elzaiat et al. 2014, Georges et al. 2014, Zhang et al. 2017). In contrast, in mice and humans, FOXL2 is expressed at embryonic stages but its role is linked specifically to postnatal folliculogenesis/granulosa cell function (Nicol \& Yao 2014, Pannetier et al. 2016). Pannetier and colleagues (2016) posited that the relative timing of sex steroidogenesis and meiosis in mammals may explain the FOXL2 dichotomy in goat versus mouse embryos (Pannetier et al. 2012). In the goat, early gonadal steroidogenesis (which may be regulated by FOXL2) precedes female meiosis, but the converse is seen in mouse. This may make the goat model more susceptible to FOXL2-mediated sex reversal. Steroidogenesis in chicken also precedes meiosis (Smith et al. 2007, 2008). The avian FOXL2 data would support this idea if FOXL2 regulates other components of the steroidogenic pathway rather than aromatase. In addition, the appearance of FOXL2+ cells in the ovarian cortex at later stages in the chicken imply a second phase role in folliculogenesis, as the cortex is considered to be the site of granulosa cell development in birds.

Embryonic male chicken gonads misexpressing FOXL2 showed no signs of ovarian development at the time point examined (E8). While misexpression blocked DMRT1, SOX9 and AMH expression, and disrupted testis cord formation, aromatase enzyme was not ectopically activated. Furthermore, knockdown of FOXL2 in female gonads did not affect aromatase expression at the stage examined (E7.8; stage 33-34). Aromatase is the rate-limiting step in oestrogen synthesis, and the steroid is required for proper ovarian development in birds (Scheib 1983, Elbrecht \& Smith 1992, Lambeth et al. 2013). Several studies have shown in other species that one of the functions of FOXL2 is direct activation of Aromatase (CYP19A1) gene expression, and indeed stimulation of multiple steroidogenic genes (Pisarska et al. 2004, Pannetier et al. 2006, Wang et al. 2007, Rosario et al. 2012, Sridevi et al. 2012). The failure to observe a downregulation of aromatase following FOXL2 knockdown is surprising. However, a caveat to these studies is that FOXL2 expression was knocked down, not knocked out, so some residual FOXL2 expression may have been sufficient to activate aromatase (CYP19A1 gene). We did not quantify the level of FOXL2 knockdown in this study or conduct a time course of knockdown. In chicken, oestrogen synthesised by aromatase stimulates further aromatase expression, and so it may be self-sustaining after around E6, and hence, independent of FOXL2 by the stage examined here (E8; stage 33).
Some studies in mice and humans have reported a repressive effect of FOXL2 on Aromatase (Bentsi-Barnes et al. 2010, Kuo et al. 2012, Dai et al. 2013). Despite co-localisation in medullary cord cells, a functional link between FOXL2 and aromatase has not been reported in the chicken embryo. FOXL2 is expressed in mature granulosa cells of the adult chicken ovary (Govoroun et al. 2004). Wang and colleagues have studied FOXL2 function in hen granulosa and thecal cells. After FOXL2 overexpression in culture granulosa cells, they reported upregulation of genes involved in focal adhesion, among others, but CYP19A1 was not upregulated (Wang, et al. 2017). In a separate study, the same authors studied theca cells, which strongly express aromatase in the hen. Steroidogenic factor 1 (SF1) but not FOXL2 was able to activate the aromatase promoter in vitro (Wang \& Gong 2017).

Taken together with the embryonic data shown here, these observations suggest that FOXL2 alone may not activate aromatase in the chicken model. Hence, at embryonic stages, misexpression of FOXL2 in male gonads may be insufficient to activate aromatase, and another factor may be required. A good candidate at embryonic stages is SF1. SFI can synergise with FOXL2 to activate gonadal-expressed genes (Pisarska et al. 2004, Park et al. 2010, Jin et al. 2016), and SF1 expression levels are lower in male embryonic chicken gonads compared to females (Smith et al. 1999). It would be of interest for ectopically expressing both FOXL2 and SF1 in males. In mammals, other proposed FOXL2 co-factors include Activin-A (Pannetier et al. 2006, Belli et al. 2018) and the Nobox transcription factor (Bouilly et al. 2014). In the case of FOXL2 knockdown, Fig. 5 shows FOXL2 loss in female gonads and ectopic activation of SOX9, but no perturbation of aromatase. If FOXL2 does activate aromatase in chicken, other female factors may substitute for FOXL2 loss in females, such as SF1 or other FOX family members, which are present in the gonads (Ayers et al. 2013). FOXL2 is expressed in the same cell type as aromatase in the chicken embryo: the medullary cord cells of females. In support of a more complex relationship between FOXL2 and aromatase in the chicken is the observation that, at E8.5 and at E14.5, some cells were detected that expressed FOXL2 only or aromatase only. This may reflect variation in the timing of gene expression. Cells only expressing FOXL2 may not yet have activated aromatase, while those only expressing aromatase may have shut off FOXL2. The alternative scenario is that some FOXL2-positive cells do not activate aromatase, while in other cells there are alternative activators of 
aromatase. This would imply different sub-populations of FOXL2-expressing cells. This has been reported in mouse, in which distinct sub-populations of FOXL2-expressing cells have been described (Gustin et al. 2016). Lastly, a typical female gonadal cortex persisted in FOXL2knockdown gonads (Fig. 8), and this is not surprising, given that aromatase was unaffected. The oestrogen synthesised by aromatase is thought to stimulate cortex formation in chicken (Vaillant et al. 2001).

One consideration relevant to both the overexpression and knockdown studies reported here is the timing of gonadal development. Gonads were examined at embryonic day 8 (stage 33). It is possible that examination of gonads at later stages might reveal changes in gene expression not seen earlier. More widespread ectopic activation of $\mathrm{AMH}$, for example, might be more apparent at later stage knockdown gonads, given that SOX9 is considered to activate or at least maintain AMH expression. Embryonic day 8 (HH stage 33) was chosen because gonadal sex differentiation is typically well advanced at this developmental time point. Ectopic expression of FOXL2 in male gonads, for example, repressed DMRT1, SOX9 and $\mathrm{AMH}$ (testis markers) at E8 but did not induce aromatase. Conversely, FOXL2 knockdown induced ectopic SOX9 and AMH expression in females without inducing DMRT1, nor affecting aromatase. It is possible that at later stages, aromatase might be activated and repressed by virally driven FOXL2 overexpression and knockdown, respectively. Similarly, an examination of gonads at later stages beyond E8 might reveal activation of DMRT1 and after FOXL2 knockdown. However, as noted above, DMRT1 may not be activated in female (ZW) gonads following FOXL2 knockdown due to the single dosage of the gene (ZW genotype), based upon the DMRT1 Z dosage hypothesis for avian sex determination.

In mammals, FOXL2 has diverse roles that centre around ovarian development, including inhibition of male pathway genes, modulation of steroidogenesis and activation of female pathway genes, such as follistatin. Follistatin is expressed female specifically in the chicken embryo (Smith unpubl. obs.). FOXL2 also has an effect on cell proliferation. At embryonic stages in mouse, FOXL2 is expressed in mitotically arrested cells (Mork et al. 2012, Gustin et al. 2016) and the gene is associated with cell cycle repression (Nicol et al. 2018). This may also apply in chicken, as the medullary cord cells are not a highly proliferative population in females. In summary, we describe the first functional analysis of FOXL2 in birds. As in mammals, reptile and fishes, chicken FOXL2 is expressed female specifically during gonadogenesis. Overexpression and knockdown experiments show that FOXL2 antagonises male pathway genes in chicken, most notably SOX9. In this regard, the role of FOXL2 in chicken is more similar to that defined for the goat and fishes, where the gene is ascribed a clear function in embryonic gonadal sex determination. However, in the goat model, repression of FOXL2 in females first leads to an activation of DMRT1, followed by SOX9 (Boulanger et al. 2014, Elzaiat et al. 2014). Here, we report the activation of SOX9 rather than DMRT1 after FOXL2 repression in chicken. As noted above, this could be due to the sex linkage of DMRT1 in birds, where the females only have one copy. Under this scenario, the lower level of DMRT1 in female gonads allows FOXL2 expression, which antagonises SOX9 rather than DMRT1. To definitely test the role of FOXL2 in chicken gonadal development, genome editing could be used. Recent advances in the application of CRISPR/Cas9 technology to avian models now make this approach feasible. It will also be worthwhile to define the upstream factors regulating FOXL2 in chicken. We postulate that a negative regulator in males would be DMRT1.

\section{Declaration of interest}

The authors declare that there is no conflict of interest that could be perceived as prejudicing the impartiality of the research reported.

\section{Funding}

This research was funded by the Australian Research Council grant numbers ARC DP160103881 and ARC DP 160104638.

\section{References}

Ahn H, Sim J, Abdul R, Chung MS, Paik SS, Oh YH, Park CK \& Jang K 2015 Increased expression of forkhead box M1 is associated with aggressive phenotype and poor prognosis in estrogen receptorpositive breast cancer. Journal of Korean Medical Science 30 390-397. (https://doi.org/10.3346/jkms.2015.30.4.390)

Auguste A, Chassot AA, Gregoire EP, Renault L, Pannetier M, Treier M, Pailhoux E \& Chaboissier MC 2011 Loss of R-spondin1 and Foxl2 amplifies female-to-male sex reversal in XX mice. Sexual Development 5 304-317. (https://doi.org/10.1159/000334517)

Ayers KL, Davidson NM, Demiyah D, Roeszler KN, Grutzner F, Sinclair AH, Oshlack A \& Smith CA 2013 RNA sequencing reveals sexually dimorphic gene expression before gonadal differentiation in chicken and allows comprehensive annotation of the W-chromosome. Genome Biology 14 R26. (https://doi.org/10.1186/ gb-2013-14-3-r26)

Baron D, Cocquet J, Xia X, Fellous M, Guiguen Y \& Veitia RA 2004 An evolutionary and functional analysis of FoxL2 in rainbow trout gonad differentiation. Journal of Molecular Endocrinology 33 705-715. (https:// doi.org/10.1677/jme.1.01566) 
Baron D, Batista F, Chaffaux S, Cocquet J, Cotinot C, Cribiu E, De Baere E, Guiguen Y, Jaubert F, Pailhoux E, et al. 2005 Foxl2 gene and the development of the ovary: a story about goat, mouse, fish and woman. Reproduction, Nutrition, Development 45 377-382. (https://doi. org/10.1051/rnd:2005028)

Barske LA \& Capel B 2010 Estrogen represses SOX9 during sex determination in the red-eared slider turtle Trachemys scripta. Developmental Biology 341 305-314. (https://doi.org/10.1016/j.ydbio.2010.02.010)

Batista F, Vaiman D, Dausset J, Fellous M \& Veitia RA 2007 Potential targets of FOXL2, a transcription factor involved in craniofacial and follicular development, identified by transcriptomics. PNAS 104 3330-3335. (https://doi.org/10.1073/pnas.0611326104)

Belli M, Iwata N, Nakamura T, Iwase A, Stupack D \& Shimasaki S 2018 FOXL2C134W-induced CYP19 expression via cooperation With SMAD3 in HGrC1 cells. Endocrinology 159 1690-1703. (https://doi. org/10.1210/en.2017-03207)

Benayoun BA, Kalfa N, Sultan C \& Veitia RA 2010 The forkhead factor FOXL2: a novel tumor suppressor? Biochimica and Biophysica Acta 1805 1-5. (https://doi.org/10.1016/j.bbcan.2009.09.002)

Bentsi-Barnes IK, Kuo FT, Barlow GM \& Pisarska MD 2010 Human forkhead L2 represses key genes in granulosa cell differentiation including aromatase, P450scc, and cyclin D2. Fertility and Sterility 94 353-356. (https://doi.org/10.1016/j.fertnstert.2009.09.050)

Bertho S, Pasquier J, Pan Q, Le Trionnaire G, Bobe J, Postlethwait JH, Pailhoux E, Schartl M, Herpin A \& Guiguen Y 2016 Foxl2 and its relatives are evolutionary conserved players in gonadal sex differentiation. Sexual Development 10 111-129. (https://doi. org/10.1159/000447611)

Bertho S, Herpin A, Branthonne A, Jouanno E, Yano A, Nicol B, Muller T, Pannetier M, Pailhoux E, Miwa M, et al. 2018 The unusual rainbow trout sex determination gene hijacked the canonical vertebrate gonadal differentiation pathway. PNAS 115 12781-12786. (https:// doi.org/10.1073/pnas.1803826115)

Beysen D, Vandesompele J, Messiaen L, De Paepe A \& De Baere E 2004 The human FOXL2 mutation database. Human Mutation 24 189-193. (https://doi.org/10.1002/humu.20079)

Bouilly J, Veitia RA \& Binart N 2014 NOBOX is a key FOXL2 partner involved in ovarian folliculogenesis. Journal of Molecular Cell Biology 6 175-177. (https://doi.org/10.1093/jmcb/mju006)

Boulanger L, Pannetier M, Gall L, Allais-Bonnet A, Elzaiat M, Le Bourhis D, Daniel N, Richard C, Cotinot C, Ghyselinck NB, et al. 2014 FOXL2 is a female sex-determining gene in the goat. Current Biology 24 404-408. (https://doi.org/10.1016/j.cub.2013.12.039)

Brummelkamp TR, Bernards R \& Agami R 2002 A system for stable expression of short interfering RNAs in mammalian cells. Science 296 550-553. (https://doi.org/10.1126/science.1068999)

Brunet A, Bonni A, Zigmond MJ, Lin MZ, Juo P, Hu LS, Anderson MJ, Arden KC, Blenis J \& Greenberg ME 1999 Akt promotes cell survival by phosphorylating and inhibiting a Forkhead transcription factor. Cell 96 857-868. (https://doi.org/10.1016/s0092-8674(00)80595-4)

Castro JR \& Trujillo NP 2002 Mutations in FOXL2 underlying BPES (types 1 and 2) in Colombian families. American Journal of Medical Genetics 113 47-51. (https://doi.org/10.1002/ajmg.10741)

Cepko CL, Ryder E, Austin C, Golden J, Fields-Berry S \& Lin J 1998 Lineage analysis using retroviral vectors. Methods 14 393-406. (https://doi.org/10.1006/meth.1998.0594)

Clark KL, Halay ED, Lai E \& Burley SK 1993 Co-crystal structure of the HNF-3/fork head DNA-recognition motif resembles histone H5. Nature 364 412-420. (https://doi.org/10.1038/364412a0)

Clinton M, Haines L, Belloir B \& McBride D 2001 Sexing chick embryos: a rapid and simple protocol. British Poultry Science 42 134-138. (https:// doi.org/10.1080/713655025)

Cocquet J, Pailhoux E, Jaubert F, Servel N, Xia X, Pannetier M, De Baere E, Messiaen L, Cotinot C, Fellous M, et al. 2002 Evolution and expression of FOXL2. Journal of Medical Genetics 39 916-921. (https:// doi.org/10.1136/jmg.39.12.916)
Cocquet J, De Baere E, Gareil M, Pannetier M, Xia X, Fellous M \& Veitia RA 2003 Structure, evolution and expression of the FOXL2 transcription unit. Cytogenetic and Genome Research 101 206-211. (https://doi.org/10.1159/000074338)

Corpuz PS, Lindaman LL, Mellon PL \& Coss D 2010 FoxL2 Is required for activin induction of the mouse and human follicle-stimulating hormone beta-subunit genes. Molecular Endocrinology 24 1037-1051. (https://doi.org/10.1210/me.2009-0425)

Crisponi L, Deiana M, Loi A, Chiappe F, Uda M, Amati P, Bisceglia L, Zelante L, Nagaraja R, Porcu S, et al. 2001 The putative forkhead transcription factor FOXL2 is mutated in blepharophimosis/ptosis/ epicanthus inversus syndrome. Nature Genetics 27 159-166. (https:// doi.org/10.1038/84781)

Dai A, Sun H, Fang T, Zhang Q, Wu S, Jiang Y, Ding L, Yan G \& Hu Y 2013 MicroRNA-133b stimulates ovarian estradiol synthesis by targeting Foxl2. FEBS Letters 587 2474-2482. (https://doi.org/10.1016/j. febslet.2013.06.023)

De Baere E, Dixon MJ, Small KW, Jabs EW, Leroy BP, Devriendt K, Gillerot Y, Mortier G, Meire F, Van Maldergem L, et al. 2001 Spectrum of FOXL2 gene mutations in blepharophimosis-ptosis-epicanthus inversus (BPES) families demonstrates a genotype-phenotype correlation. Human Molecular Genetics 10 1591-1600. (https://doi. $\operatorname{org} / 10.1093 / \mathrm{hmg} / 10.15 .1591)$

De Baere E, Lemercier B, Christin-Maitre S, Durval D, Messiaen L, Fellous M \& Veitia R 2002 FOXL2 mutation screening in a large panel of POF patients and XX males. Journal of Medical Genetics 39 e43. (https://doi.org/10.1136/jmg.39.8.e43)

Deng L, Liu T, Zhang B, Wu H, Zhao J \& Chen J 2017 Forkhead box C1 is targeted by microRNA-133b and promotes cell proliferation and migration in osteosarcoma. Experimental and Therapeutic Medicine 14 2823-2830. (https://doi.org/10.3892/etm.2017.4870)

Eelen G, Verlinden L, Maes C, Beullens I, Gysemans C, Paik JH, DePinho RA, Bouillon R, Carmeliet G \& Verstuyf A 2016 Forkhead box $\mathrm{O}$ transcription factors in chondrocytes regulate endochondral bone formation. Journal of Steroid Biochemistry and Molecular Biology 164 337-343. (https://doi.org/10.1016/j.jsbmb.2015.07.015)

Elbrecht A \& Smith RG 1992 Aromatase enzyme activity and sex determination in chickens. Science 255 467-470. (https://doi org/10.1126/science.1734525)

Ellsworth BS, Egashira N, Haller JL, Butts DL, Cocquet J, Clay CM, Osamura RY \& Camper SA 2006 FOXL2 in the pituitary: molecular, genetic, and developmental analysis. Molecular Endocrinology 202796 2805. (https://doi.org/10.1210/me.2005-0303)

Elzaiat M, Jouneau L, Thepot D, Klopp C, Allais-Bonnet A, Cabau C, Andre M, Chaffaux S, Cribiu EP, Pailhoux E, et al. 2014 Highthroughput sequencing analyses of XX genital ridges lacking FOXL2 reveal DMRT1 up-regulation before SOX9 expression during the sexreversal process in goats. Biology of Reproduction 91 153. (https://doi. org/10.1095/biolreprod.114.122796)

Fleming NI, Knower KC, Lazarus KA, Fuller PJ, Simpson ER \& Clyne CD 2010 Aromatase is a direct target of FOXL2: C134W in granulosa cell tumors via a single highly conserved binding site in the ovarian specific promoter. PLoS ONE 5 e14389. (https://doi.org/10.1371/ journal.pone.0014389)

Garcia-Ortiz JE, Pelosi E, Omari S, Nedorezov T, Piao Y, Karmazin J, Uda M, Cao A, Cole SW, Forabosco A, et al. 2009 Foxl2 functions in sex determination and histogenesis throughout mouse ovary development. BMC Developmental Biology 9 36. (https://doi. org/10.1186/1471-213X-9-36)

Georges A, Auguste A, Bessiere L, Vanet A, Todeschini AL \& Veitia RA 2014 FOXL2: a central transcription factor of the ovary. Journal of Molecular Endocrinology 52 R17-R33. (https://doi.org/10.1530/ JME-13-0159)

Govoroun MS, Pannetier M, Pailhoux E, Cocquet J, Brillard JP, Couty I, Batellier F \& Cotinot C 2004 Isolation of chicken homolog of the FOXL2 gene and comparison of its expression patterns with those of 
aromatase during ovarian development. Developmental Dynamics 231 859-870. (https://doi.org/10.1002/dvdy.20189)

Guiguen Y, Fostier A, Piferrer F \& Chang CF 2010 Ovarian aromatase and estrogens: a pivotal role for gonadal sex differentiation and sex change in fish. General and Comparative Endocrinology 165 352-366. (https://doi.org/10.1016/j.ygcen.2009.03.002)

Gustin SE, Hogg K, Stringer JM, Rastetter RH, Pelosi E, Miles DC, Sinclair AH, Wilhelm D \& Western PS 2016 WNT/beta-catenin and p27/FOXL2 differentially regulate supporting cell proliferation in the developing ovary. Developmental Biology 412 250-260. (https://doi. org/10.1016/j.ydbio.2016.02.024)

Hamburger V \& Hamilton HL 1992 A series of normal stages in the development of the chick embryo. 1951. Developmental Dynamics 195 231-272. (https://doi.org/10.1002/aja.1001950404)

Harpavat S \& Cepko CL 2006 RCAS-RNAi: a loss-of-function method for the developing chick retina. BMC Developmental Biology 6 2. (https:// doi.org/10.1186/1471-213X-6-2)

Harris SE, Chand AL, Winship IM, Gersak K, Aittomaki K \& Shelling AN 2002 Identification of novel mutations in FOXL2 associated with premature ovarian failure. Molecular Human Reproduction 8 729-733. (https://doi.org/10.1093/molehr/8.8.729)

Hirst CE, Major AT, Ayers KL, Brown RJ, Mariette M, Sackton TB \& Smith CA 2017 Sex reversal and comparative data undermine the W chromosome and support Z-linked DMRT1 as the regulator of gonadal sex differentiation in birds. Endocrinology 158 2970-2987. (https://doi.org/10.1210/en.2017-00316)

Hudson QJ, Smith CA \& Sinclair AH 2005 Aromatase inhibition reduces expression of FOXL2 in the embryonic chicken ovary. Developmental Dynamics 233 1052-1055. (https://doi.org/10.1002/dvdy.20388)

Jin H, Won M, Park SE, Lee S, Park M \& Bae J 2016 FOXL2 is an essential activator of SF-1-Induced transcriptional regulation of anti-Mullerian hormone in human granulosa cells. PLoS ONE 11 e0159112. (https:// doi.org/10.1371/journal.pone.0159112)

Katoh M \& Katoh M 2004 Human FOX gene family (review). International Journal of Oncology 25 1495-1500.

Kim SY, Weiss J, Tong M, Laronda MM, Lee EJ \& Jameson JL 2009 Foxl2, a forkhead transcription factor, modulates nonclassical activity of the estrogen receptor-alpha. Endocrinology 150 5085-5093. (https://doi. org/10.1210/en.2009-0313)

Kim JH, Yoon S, Park M, Park HO, Ko JJ, Lee K \& Bae J 2011 Differential apoptotic activities of wild-type FOXL2 and the adult-type granulosa cell tumor-associated mutant FOXL2 (C134W). Oncogene 30 16531663. (https://doi.org/10.1038/onc.2010.541)

Krupczak-Hollis K, Wang X, Kalinichenko VV, Gusarova GA, Wang IC, Dennewitz MB, Yoder HM, Kiyokawa H, Kaestner KH \& Costa RH 2004 The mouse Forkhead Box $\mathrm{m} 1$ transcription factor is essential for hepatoblast mitosis and development of intrahepatic bile ducts and vessels during liver morphogenesis. Developmental Biology 276 74-88. (https://doi.org/10.1016/j.ydbio.2004.08.022)

Kuo FT, Bentsi-Barnes IK, Barlow GM \& Pisarska MD 2011 Mutant Forkhead L2 (FOXL2) proteins associated with premature ovarian failure (POF) dimerize with wild-type FOXL2, leading to altered regulation of genes associated with granulosa cell differentiation. Endocrinology 152 3917-3929. (https://doi. org/10.1210/en.2010-0989)

Kuo FT, Fan K, Bentsi-Barnes I, Barlow GM \& Pisarska MD 2012 Mouse forkhead L2 maintains repression of FSH-dependent genes in the granulosa cell. Reproduction 144 485-494. (https://doi.org/10.1530/ REP-11-0259)

Lambeth LS, Cummins DM, Doran TJ, Sinclair AH \& Smith CA 2013 Overexpression of aromatase alone is sufficient for ovarian development in genetically male chicken embryos. PLOS ONE $\mathbf{8}$ e68362. (https://doi.org/10.1371/journal.pone.0068362)

Lambeth LS, Morris KR, Wise TG, Cummins DM, O'Neil TE, Cao Y, Sinclair AH, Doran TJ \& Smith CA 2016 Transgenic chickens overexpressing aromatase have high estrogen levels but maintain a predominantly male phenotype. Endocrinology 157 83-90. (https:// doi.org/10.1210/en.2015-1697)

Lehmann OJ, Sowden JC, Carlsson P, Jordan T \& Bhattacharya SS 2003 Fox's in development and disease. Trends in Genetics 19 339-344. (https://doi.org/10.1016/S0168-9525(03)00111-2)

Li MH, Yang HH, Li MR, Sun YL, Jiang XL, Xie QP, Wang TR, Shi HJ, Sun LN, Zhou LY, et al. 2013 Antagonistic roles of Dmrt1 and Foxl2 in sex differentiation via estrogen production in tilapia as demonstrated by TALENs. Endocrinology 154 4814-4825. (https://doi.org/10.1210/ en.2013-1451)

Loffler KA, Zarkower D \& Koopman P 2003 Etiology of ovarian failure in blepharophimosis ptosis epicanthus inversus syndrome: FOXL2 is a conserved, early-acting gene in vertebrate ovarian development. Endocrinology 144 3237-3243. (https://doi.org/10.1210/en.2002-0095)

Logan M \& Tabin C 1998 Targeted gene misexpression in chick limb buds using avian replication-competent retroviruses. Methods 14 407-420. (https://doi.org/10.1006/meth.1998.0595)

Mork L, Maatouk DM, McMahon JA, Guo JJ, Zhang P, McMahon AP \& Capel B 2012 Temporal differences in granulosa cell specification in the ovary reflect distinct follicle fates in mice. Biology of Reproduction 86 37. (https://doi.org/10.1095/biolreprod.111.095208)

Nicol B \& Yao HH 2014 Building an ovary: insights into establishment of somatic cell lineages in the mouse. Sexual Development 8 243-251. (https://doi.org/10.1159/000358072)

Nicol B, Grimm SA, Gruzdev A, Scott GJ, Ray MK \& Yao HH 2018 Genome-wide identification of FOXL2 binding and characterization of FOXL2 feminizing action in the fetal gonads. Human Molecular Genetics 27 4273-4287. (https://doi.org/10.1093/hmg/ddy312)

Ottolenghi C, Omari S, Garcia-Ortiz JE, Uda M, Crisponi L, Forabosco A, Pilia G \& Schlessinger D 2005 Foxl2 is required for commitment to ovary differentiation. Human Molecular Genetics 14 2053-2062. (https://doi.org/10.1093/hmg/ddi210)

Ottolenghi C, Pelosi E, Tran J, Colombino M, Douglass E, Nedorezov T, Cao A, Forabosco A \& Schlessinger D 2007 Loss of Wnt4 and Foxl2 leads to female-to-male sex reversal extending to germ cells. Human Molecular Genetics 16 2795-2804. (https://doi.org/10.1093/hmg/ ddm235)

Pailhoux E, Vigier B, Chaffaux S, Servel N, Taourit S, Furet JP, Fellous M, Grosclaude F, Cribiu EP, Cotinot C, et al. 2001 A 11.7-kb deletion triggers intersexuality and polledness in goats. Nature Genetics 29 453-458. (https://doi.org/10.1038/ng769)

Pailhoux E, Vigier B, Vaiman D, Servel N, Chaffaux S, Cribiu EP \& Cotinot C 2002 Ontogenesis of female-to-male sex-reversal in XX polled goats. Developmental Dynamics 224 39-50. (https://doi. org/10.1002/dvdy.10083)

Pannetier M, Fabre S, Batista F, Kocer A, Renault L, Jolivet G, MandonPepin B, Cotinot C, Veitia R \& Pailhoux E 2006 FOXL2 activates P450 aromatase gene transcription: towards a better characterization of the early steps of mammalian ovarian development. Journal of Molecular Endocrinology 36 399-413. (https://doi.org/10.1677/jme.1.01947)

Pannetier M, Elzaiat M, Thepot D \& Pailhoux E 2012 Telling the story of XX sex reversal in the goat: highlighting the sex-crossroad in domestic mammals. Sexual Development 6 33-45. (https://doi. org/10.1159/000334056)

Pannetier M, Chassot AA, Chaboissier MC \& Pailhoux E 2016 Involvement of FOXL2 and RSPO1 in ovarian determination, development, and maintenance in mammals. Sexual Development 10 167-184. (https://doi.org/10.1159/000448667)

Park M, Shin E, Won M, Kim JH, Go H, Kim HL, Ko JJ, Lee K \& Bae J 2010 FOXL2 interacts with steroidogenic factor-1 (SF-1) and represses SF-1-induced CYP17 transcription in granulosa cells. Molecular Endocrinology 24 1024-1036. (https://doi.org/10.1210/me.2009-0375)

Pisarska MD, Bae J, Klein C \& Hsueh AJ 2004 Forkhead L2 is expressed in the ovary and represses the promoter activity of the steroidogenic acute regulatory gene. Endocrinology 145 3424-3433. (https://doi org/10.1210/en.2003-1141) https://joe.bioscientifica.com

https://doi.org/10.1530/JOE-19-0277 (c) 2019 Society for Endocrinology Published by Bioscientifica Ltd. Printed in Great Britain 
Ramsey M \& Crews D 2009 Steroid signaling and temperature-dependent sex determination-reviewing the evidence for early action of estrogen during ovarian determination in turtles. Seminars in Cell and Developmental Biology 20 283-292. (https://doi.org/10.1016/j. semcdb.2008.10.004)

Rhen T, Metzger K, Schroeder A \& Woodward R 2007 Expression of putative sex-determining genes during the thermosensitive period of gonad development in the snapping turtle, Chelydra serpentina. Sexual Development 1 255-270. (https://doi.org/10.1159/000104775)

Rosario R, Araki H, Print CG \& Shelling AN 2012 The transcriptional targets of mutant FOXL2 in granulosa cell tumours. PLOS ONE 7 e46270. (https://doi.org/10.1371/journal.pone.0046270)

Scheib D 1983 Effects and role of estrogens in avian gonadal differentiation. Differentiation; Research in Biological Diversity 23 (Supplement) S87-S92. (https://www.doi.org/10.1007/978-3-642-69150-8_15)

Schmidt M, Fernandez de Mattos S, van der Horst A, Klompmaker R, Kops GJ, Lam EW, Burgering BM \& Medema RH 20022002 cell cycle inhibition by FoxO forkhead transcription factors involves downregulation of cyclin D. Molecular and Cellular Biology 227842 7852. (https://doi.org/10.1128/mcb.22.22.7842-7852.2002)

Schmidt D, Ovitt CE, Anlag K, Fehsenfeld S, Gredsted L, Treier AC \& Treier M 2004 The murine winged-helix transcription factor Foxl2 is required for granulosa cell differentiation and ovary maintenance. Development 131 933-942. (https://doi.org/10.1242/ dev.00969)

Senokuchi T, Liang CP, Seimon TA, Han S, Matsumoto M, Banks AS, Paik JH, DePinho RA, Accili D, Tabas I, et al. 2008 Forkhead transcription factors (FoxOs) promote apoptosis of insulinresistant macrophages during cholesterol-induced endoplasmic reticulum stress. Diabetes $\mathbf{5 7}$ 2967-2976. (https://doi.org/10.2337/ db08-0520)

Shah SP, Kobel M, Senz J, Morin RD, Clarke BA, Wiegand KC, Leung G, Zayed A, Mehl E, Kalloger SE, et al. 2009 Mutation of FOXL2 in granulosa-cell tumors of the ovary. New England Journal of Medicine 360 2719-2729. (https://doi.org/10.1056/NEJMoa0902542)

Smith CA \& Sinclair AH 2004 Sex determination: insights from the chicken. BioEssays 26 120-132. (https://doi.org/10.1002/bies.10400)

Smith CA, Smith MJ \& Sinclair AH 1999 Expression of chicken steroidogenic factor-1 during gonadal sex differentiation. General and Comparative Endocrinology 113 187-196. (https://doi.org/10.1006/ gcen.1998.7214)

Smith CA, Roeszler KN, Hudson QJ \& Sinclair AH 2007 Avian sex determination: what, when and where? Cytogenetic and Genome Research 117 165-173. (https://doi.org/10.1159/000103177)

Smith CA, Roeszler KN, Bowles J, Koopman P \& Sinclair AH 2008 Onset of meiosis in the chicken embryo; evidence of a role for retinoic acid. $B M C$ Developmental Biology 8 85. (https://doi.org/10.1186/1471-213X-8-85)

Smith CA, Roeszler KN, Ohnesorg T, Cummins DM, Farlie PG, Doran TJ \& Sinclair AH 2009 $a$ The avian Z-linked gene DMRT1 is required for male sex determination in the chicken. Nature 461 267-271. (https:// doi.org/10.1038/nature08298)

Smith CA, Roeszler KN \& Sinclair AH $2009 b$ Robust and ubiquitous GFP expression in a single generation of chicken embryos using the avian retroviral vector, RCASBP. Differentiation; Research in Biological Diversity 77 473-482. (https://doi.org/10.1016/j.diff.2009.02.001)

Sridevi P, Chaitanya RK, Dutta-Gupta A \& Senthilkumaran B 2012 FTZ-F1 and FOXL2 up-regulate catfish brain aromatase gene transcription by specific binding to the promoter motifs. Biochimica and Biophysica Acta 1819 57-66. (https://doi.org/10.1016/j.bbagrm.2011.10.003)

Stahl M, Dijkers PF, Kops GJ, Lens SM, Coffer PJ, Burgering BM \& Medema RH 2002 The forkhead transcription factor FoxO regulates transcription of p27Kip1 and Bim in response to IL-2. Journal of Immunology 168 5024-5031. (https://doi.org/10.4049/ jimmunol.168.10.5024)

Tran S, Zhou X, Lafleur C, Calderon MJ, Ellsworth BS, Kimmins S, Boehm U, Treier M, Boerboom D \& Bernard DJ 2013 Impaired fertility and FSH synthesis in gonadotrope-specific Foxl2 knockout mice. Molecular Endocrinology 27 407-421. (https://doi.org/10.1210/ me.2012-1286)

Uda M, Ottolenghi C, Crisponi L, Garcia JE, Deiana M, Kimber W, Forabosco A, Cao A, Schlessinger D \& Pilia G 2004 Foxl2 disruption causes mouse ovarian failure by pervasive blockage of follicle development. Human Molecular Genetics 13 1171-1181. (https://doi. org/10.1093/hmg/ddh124)

Uhlenhaut NH \& Treier M 2006 Foxl2 function in ovarian development. Molecular Genetics and Metabolism 88 225-234. (https://doi. org/10.1016/j.ymgme.2006.03.005)

Uhlenhaut NH, Jakob S, Anlag K, Eisenberger T, Sekido R, Kress J, Treier AC, Klugmann C, Klasen C, Holter NI, et al. 2009 Somatic sex reprogramming of adult ovaries to testes by FOXL2 ablation. Cell 139 1130-1142. (https://doi.org/10.1016/j.cell.2009.11.021)

Vaillant S, Dorizzi M, Pieau C \& Richard-Mercier N 2001 Sex reversal and aromatase in chicken. Journal of Experimental Zoology 290 727-740. (https://doi.org/10.1002/jez.1123)

Vaillant S, Guemene D, Dorizzi M, Pieau C, Richard-Mercier N \& Brillard JP 2003 Degree of sex reversal as related to plasma steroid levels in genetic female chickens (Gallus domesticus) treated with fadrozole. Molecular Reproduction and Development 65 420-428. (https://doi.org/10.1002/mrd.10318)

Veitia RA 2010 FOXL2 versus SOX9: a lifelong "battle of the sexes". BioEssays 32 375-380. (https://doi.org/10.1002/bies.200900193)

Wang J \& Gong Y 2017 Transcription of CYP19A1 is directly regulated by SF-1 in the theca cells of ovary follicles in chicken. General and Comparative Endocrinology 247 1-7. (https://doi.org/10.1016/j. ygcen.2017.03.013)

Wang DS, Kobayashi T, Zhou LY, Paul-Prasanth B, Ijiri S, Sakai F, Okubo K, Morohashi K \& Nagahama Y 2007 Foxl2 up-regulates aromatase gene transcription in a female-specific manner by binding to the promoter as well as interacting with ad4 binding protein/steroidogenic factor 1. Molecular Endocrinology 21 712-725. (https://doi.org/10.1210/ me.2006-0248)

Wang J, Zhao C, Li J, Feng Y \& Gong Y 2017 Transcriptome analysis of the potential roles of FOXL2 in chicken pre-hierarchical and pre-ovulatory granulosa cells. Comparative Biochemistry and PhysiologyPart D: Genomics and Proteomics 21 56-66. (https://doi.org/10.1016/j. cbd.2016.12.003)

Yang YJ, Wang Y, Li Z, Zhou L \& Gui JF 2017 Sequential, divergent, and cooperative requirements of Foxl2a and Foxl2b in ovary development and maintenance of zebrafish. Genetics 205 1551-1572. (https://doi. org/10.1534/genetics.116.199133)

Zhang X, Li M, Ma H, Liu X, Shi H, Li M \& Wang D 2017 Mutation of foxl2 or cyp19a1a results in female to male sex reversal in XX Nile tilapia. Endocrinology 158 2634-2647. (https://doi.org/10.1210/ en.2017-00127)

Received in final form 30 August 2019

Accepted 9 September 2019

Accepted Preprint published online 9 September 2019 https://joe.bioscientifica.com https://doi.org/10.1530/JOE-19-0277 (c) 2019 Society for Endocrinology Published by Bioscientifica Ltd. Printed in Great Britain 